\title{
Spænding, samspil og frisættelse: En undersøgelse af forholdet mellem inkarnation og eskatologi i Grundtvigs salme "Midt iblandt os er Guds Rige"
}

\author{
Af Aage Schiøler
}

I teksten afdækkes en række spændings- og balanceelementer, der viser sig bestemt af en dynamisk opfattelse af inkarnationen, som derved fremtræder som drivkraft i historie og samfundsliv. Dens endemål ses som en befriende afklaring, der hævdes at vise det nutidige fællesskab med den i Ordet og Ånden nærværende Kristus, der oprettes i dåben og opretholdes i nadveren, som det autentiske menneskeliv, i salmen kaldet Guds Rige. I forbindelse med analysen af samspillet mellem enkeltheder og helhed $i$ henholdsvis str. 1 og resten af salmen inddrages den japanske digtform haiku. Herigennem tydeliggøres samspillet som et forhold med betydningsbærende funktion.

Som introduktion fremsættes den tese, at menneskelivets autentiske vilkår kommer til stede, når nadveren fejres i menigheden med Ånden og Ordet forstået som integreret enhed og handlingens aktør (str. 1). I hoveddelen karakteriseres først den form, dette vilkår har i nutiden, ved at stille dets manglende synlighed over for den umiddelbare reaktion på den tiltale, der udgår fra virkningshistorien efter Jesus fra Nazareth (str. 2-4). Dernæst sættes tiltalen og reaktionen på den i forhold til mere indholdsbestemte udtryk for vilkårets egenart og for den indvirkning, det forventes at have på menneskets umiddelbare opfattelse af sig selv (str. 5-6). Til sidst behandles i billedsprog de følger, det autentiske vilkårs tilstedeværelse må medføre mennesker imellem nu og i en fremtid, der fører helt ud til erkendelsens tidslige grænse, som beskrives med udtryk hentet fra traditionen om Kristi Genkomst. Der forudses en endelig afklaring af og forståelse for, at menneskelivets autenti er afhængig af, at det er inddraget i Jesu historie (str. 7-9).

\section{Tekstens introduktion}

Enkeltheder i str. 1

\section{Oplæg}

Strofen bruger det fra Bibelen kendte billede af måltidet som stedet for Guds nærvær hos mennesker, eksempelvis 1 Mos 18,1-15. S1 23,5-6. Es 25,6. Luk 14,15-24. I strofen præciseres billedet gennem talen om, 
at ved nadveren er enheden af Guds Aand og Guds Ord nærværets bærere:

Midt iblandt os er Guds Rige

Med Guds Aand og i Guds Ord,

I Guds Menighed tillige:

Giæster ved Hans Naadebord!

(GSV IV, str. 1, 344)

\section{Guds Rige som livsvilkår}

Beskrivelsen af Guds Riges nærvær er klar i hovedtrækkene, men ikke umiddelbart entydig i alle enkeltheder. Klarheden kommer af, at måltidet med deltagerne samlet omkring bordet er en almenmenneskelig erfaring i vores kulturkreds. Den manglende entydighed opstår i vekselvirkningen mellem de tilstedeværende, hvis forskellige karakter og roller ved måltidet kræver uddybning. Der er tale om en balanceakt mellem det sansede, synlige, håndfaste: måltidet med den deltagende menighed, og de usynligt nærværende repræsentanter for Guds Rige: Aanden og Ordet, og om valgmuligheder med hensyn til, om enkeltudsagn skal henføres til den ene eller den anden part.

Da teksten er af Grundtvig, forekommer det nærliggende, næsten uundgåeligt, at minde om hans hyppige identifikation af Kristus og Ordet ud fra Johs 1,2.14. Meget tydeligt ses det i udsagnet om Peter i salmen "Der sad en Fisker saa tankefuld", 1838 (GSV II, 229-231): "Hos Ordet gik han i Skole" (str. 7).

Billedet af måltidet ser ikke Guds Riges nærvær som opretholdelsen af en bestemt organisation, en given retstilstand eller en særlig moralkodeks, men som et personligt bestemt præg på det menneskelige samvær. Det peger i retning af, at "Naadebord" i v. 4 er inspireret af lignelsen om det store gæstebud, der gennemføres uanset gentagne afslag fra udvalgte gæster (Luk 14,15-24), så meget mere som Grundtvig selv i salmen "Beredt er nu til Nadver stor", 1845, siger:

Beredt er nu til Nadver stor

Den bedste Konges Naadebord,

Hans Tjenere paa Veien staae,

Og byde hver, som vil, indgaae.

(GSV IV, str. 2, 111)

På den måde karakteriseres Guds Rige som et livsvilkår, der er tiltænkt alle. Efter Jesu opstandelse ser de ældste menigheder nadveren i gudstjenesten som denne indbydelses centrale fremtrædelsesform. I forbindelse med omdelingen af brød og vin tales der i 1 Kor 10,16-17 om fællesskab med Kristi legeme og Kristi blod, det vil sige hans personlige livsform og livsskæbne, og i 1 Kor 11,23-26, bruges indstiftelsesordene til at tolke nadvernydelsen som forkyndelse af den 
korsfæstede Herres og Frelsers nærvær, "indtil han kommer", så indbydelsen også i tid er tiltænkt alle.

\section{Betydningen af "tillige"}

Udtrykket "I Guds Menighed tillige" i v. 3 giver anledning til at overveje forholdet mellem Guds Rige og Guds Menighed. Som nævnt må Guds Rige ses som et livsvilkår, der skabes hos os "Med Guds Aand og i Guds Ord". Skulle v. 3 tolkes på den måde, at dette vilkår 'også' er i menigheden, bliver følgen, at fremtrædelsesformen for Guds Riges nærvær kan være den samme uden for menigheden som i menigheden.

Selvfølgelig råder Gud også uden for menigheden, og også dér er Ånden og Ordet på færde. I Grundtvigs bibelsk inspirerede tankegang skylder tilværelsen til alle tider Ordet og Ånden sin eksistens, som det kan ses af digtet "I Begyndelsen var Ordet", 1860-62 (GSV V, 337340). Der er selvfølgelig klar afhængighed af Gen 1,2-3: "og Guds ånd svævede over vandene. Gud sagde".

Guds Ord i den specifikke betydning: Guds åbenbarede ord i Jesus Kristus, lader sig imidlertid alene høre i menigheden, ja, menigheden bliver til ved, at Ordet i denne betydning gennem Åndens indgriben lader sig høre og gør sig troet mellem mennesker. Det fremgår af, at det er i denne forbindelse, "I Begyndelsen var Ordet" med brug af dobbeltheden "Guddoms-Ordet fra det Høie" og "det matte GienlydsOrd / Paa Jordklimpens Tunge" kan tale om "et Himmerig paa Jord" $(G S V \mathrm{~V}$, str. 5, 339). Det er ud fra den samme tankegang, menigheden i salmen "Kirken det er et gammelt Huus", 1836 og 1853 (GSV I 7981, VI/1, 10-11, kan kaldes "Kirken af levende Stene", der bedst bygges af Ånden og alene helliges af Ordet (str. 9, 81).

Naturligvis kan Grundtvig have været uopmærksom et øjeblik, da han skrev v. 3, og overset, at hvis Guds Ord tages i den videre betydning med inklusion af skaberordet, bliver "i Guds Menighed tillige" i betydningen 'også i Guds menighed' inderligt overflødigt. Guds skaberord virker jo overalt. Ellers var intet til. Den tætte form digtet igennem tyder dog ikke på, at han har tilladt sig en sådan lapsus $\mathrm{i}$ forhold til et kernepunkt i sin egen teologi. Det mest nærliggende er at forstå "Guds Ord" i v. 2 om Kristus og "tillige" i v. 3 som "i ubrydelig enhed med hinanden'.

\section{“Giæster" som verbum activum}

Det kolon, der afslutter v 3, viser, at v. 4 er en nærmere bestemmelse af noget foranstående, sådan som "Tro og Haab og Kiærlighed" i str. 8 , v. 2, nærmere bestemmer det foranstående "den gode Jord hernede". 
I den forbindelse bliver spørgsmålet, hvem bestemmelsen gælder, og hvordan "Giæster" skal forstås.

Der kan være tale om, at "Guds Menighed" bestemmes som gæster ligesom i "Kraften fra det Høie", 1850, med linjerne: "Kraften fra det Høie, / Guds Aand os sammenføie / (...) / Til Giæster ved Vorherres Bord" (GSV IV, str. 2, 252). Det er også muligt, at det drejer sig om en parallel til talen om "den Største" som initiativtagende gæst ved bordet i "Tør end nogen ihukomme", 1825 (GSV I, 60-63), som Grundtvig omskrev og forkortede til Festsalmer, 6. opl., 1854 (GSV VI/1, 8-9). I den møder vi linjerne:

Vi af bløde Bøge-Stammer,

Under Nattergale-Sang,

Bygge kun et Giæste-Kammer

Til en himmelsk Alter-Gang!

VerdensVise, Jordens Bolde,

Vil vor Hytte vel forsmaae,

Men den Største vil dog holde

Nadver i den ringe Vraa;

(GSV I, str. 9-10, 62)

Det fælles er, at "Kraften fra det Høie" og den Største omdanner måltidet til Vorherres Bord og Nadver. Tanken om de tilrejsendes bidrag til traktementet, der sætter et helt afgørende præg på samværet og dets følger, og som er det væsentligste element ved nadveren i disse salmer, har sin oprindelse i fortællingerne i Luk 24,13-49.

Her er den Opstandne først gæst hos de to, han har fulgtes med på vejen fra Jerusalem til Emmaus, og senere den samme aften besøger han de forsamlede Jesus-tilhængere i Jerusalem. Begge gange forandres et måltid til nadver: 'nådebord', 'Vorherres bord'. Den ene gang nævnes måltidet direkte, den anden markeres det af, at der rækkes den Opstandne et stykke stegt fisk. Følgen bliver i begge tilfælde, at deltagerne ikke kan blive siddende. I Emmaus motiveres de til straks at bryde op. I Jerusalem făr de besked om, at det, der er sket med Jesus fra Nazareth, skal meddeles til "alle folkeslagene".

En anden, også dynamisk, gæsteoptræden beskrives kortfattet $\mathrm{i} A ̊ b$ 3,14-21. Her er en fornyelse af en menighed, der "er lunken og hverken varm eller kold”, påkrævet. Derfor lyder det som ord fra den Opstandne og Himmelfarne: "Se, jeg står ved døren og banker på; hører nogen mig og åbner døren, vil jeg gå ind til ham og holde måltid med ham og han med mig”, hvorpå der følger et løfte om sejr. I verslinjerne

Skal Jesus Christus hemmelig

Os giæste og berige,

Vi og maa troe, han er i Dig, 
Og Du i ham tillige!

(GSV IV, str. 3, 204)

fra salmen "Gud-Helligaand, vor Trøstermand!", 1846 (GSV IV, 203205), kan "giæste og berige" ses som hen-dia-dyoin, tilmed også i en sammenhæng, hvor "tillige" bruges om den ubrydelige enhed mellem guddommens anden og tredje person. Her læses "giæste" naturligt som 'bespise' i overensstemmelse med den gammeldanske sprogbrug.

Da Guds Aand og Guds Ord i "Midt iblandt os" ikke er passive størrelser, men dynamiske aktører, er det mest nærliggende at se v. 4 som en nærmere beskrivelse af deres fælles funktion i menigheden som Guds Riges repræsentation, der gør måltidet til "Naadebord". Således opfattes "Giæster" også her som verbum activum.

\section{Hjoelp hos japanerne}

\section{Haiku som parafrasemønster}

Det er tydeligt, at Grundtvig har så meget på hjerte, at den almindelige syntaks dårligt rummer det inden for strofens rammer. Et klart tegn på det er, at "tillige" i v. 3 og "Giæster" i v. 4 giver anledning til overvejelse, selv om de uanset betydning ikke sprænger billedets grundstruktur. Den korte strofe må ses som en integreret helhed, hvor de enkelte elementer giver deres bidrag til betydningen gennem den måde, de belyser hinanden på. Man bringes til at tænke på det, HansJørgen Nielsen i bogen Haiku omtaler som sprængt syntaks (Nielsen $1963,7)$. Desuden, siger han, betjener "denne digtform sig af det konkrete, deskriptive billede på bekostning af den personlige metafor" (Nielsen 1963, 169), en præcis beskrivelse også af Grundtvigs strofe. Endelig viser udvalget af digte (Nielsen 1963, 11-161), at en treleddet form er den sædvanlige i denne digtning, sådan som der også er tre led i "Midt iblandt os", str. 1.

I det lys lader strofen sig parafrasere $\mathrm{i}$ en form, der minder om haiku:

Imellem os

Guds råderum

Guds Ånd, Guds Ord

én i Guds Folk

Byder til bordet

åbent for alle

På den baggrund gennemgås to haiku, der berører to motiver, som også forekommer i Grundtvigs strofe, nemlig gæstemotivet og mødet mellem, hvad der i teksterne beskrives som to forskellige livsverdener. 


\section{Fællesmotiver i to haiku}

Den første haiku inddrager en udenforstående i et tavst samvær:

\section{Værten}

hans gæst

En hvid

krysantemum

Alle tre

uden et ord

(Nielsen 1963, 65)

Digtet begynder med gæstemotivet og slutter med en karakteristik af dets resultat. Det mellemliggende led henvender sig til synssansen. Hos Grundtvig indledes med resultatet og afsluttes med gæstemotivet, og i mellemleddet har sproget gennem Guds Ord den rolle, der svarer til blomstens hos japanerne.

For så vidt den hvide krysantemum i Japan er knyttet til døden, mens ånd og ord hos Grundtvig bærer livet, bringer de to tekster også hver sit af disse to aspekter på tilværelsen i spil. I den forbindelse må det imidlertid huskes, at i den Zen-inspirerede eksistensforståelse, der ligger bag haiku-digtningen, ses liv og død snarere som komplementære størrelser end som den fuldstændige modsætning, de betegner hos Grundtvig.

I den anden haiku overlejrer to forskellige naturfænomeners bevægelsesmønstre hinanden på den samme lokalitet:

En ørred
springer
På bækkens
bund
Rejser
skyerne
(Nielsen 1963, 61)

Spejlbilledet på bækkens bund af både fisk og skyer viser det synliges stadige omskiftelighed og dets stedse forsvindende karakter. På den måde er denne haiku et ypperligt eksempel på "det blivendes sammenstød med det foranderlige", der tænkes at viderebringe helheder, "som unddrager sig sproget", det, der "sker på dette sted, i dette øjeblik" (Nielsen 1963, 171).

Hos Grundtvig er det dynamiske ikke på samme måde spændt op imod det statiske ved fordeling mellem strofens tre led. Modstillingen ses i dem alle tre. I første og sidste led, hvor "Midt iblandt os" og "Naadebord" er statiske elementer, er der også dynamik på færde. 
Guds Rige er jo ikke et fast, administrativt apparat, men en befriende funktion (Luk 11,14-20). Ved "hans Naadebord" sidder man ikke mageligt henslængt til evig tid. Der kommer nogen på besøg, den besøgende uddeler mad og drikke, og det hele får varige følger (Luk 24,13-45). I det mellemste led står det dynamiske i forgrunden, fordi foreningen af Ånd og Ord har en befriende funktion og skaber råderum, men det foranlediges af et ubrydeligt sammenhold, som det fremgår af 'tillige' i betydning 'i fællesskab', og det foregår inden for en forsamling med sit eget præg, 'Guds Menighed'.

\section{Katalysatorfunktionen}

De mellemste led i begge haiku lader sig opfatte som en art katalysatorer, elementer, der ikke forandrer sig ved at være med i en proces, men er nødvendige for, at den foregår på rette måde.

Når samværet er forbi, er blomsten stadig hvid og ude af stand til at sige noget. Alligevel har den foranlediget en enhed, som ellers ikke ville være. Værten og gæsten er begge taget ind i den hvide krysantemums verden (døden?), skønt ingen af dem er blomster. Når ørreden er tilbage i vandet, og skyerne er drevet af sted, er bækkens bund stadig almindeligt sand. Alligevel medvirker det statiske elements tilstedeværelse i teksten til, at der ved afslutningen er sket noget med de bevægelige elementer. Forholdet mellem dem og opfattelsen af dem har ændret karakter. Fisken, der hører hjemme under vandet, men springer ud af det, og skyerne, der hænger under himlen, men spejler sig på bækkens bund, ses som sammenhørende væsner trods deres forskellige art, sammensætning og vilkår og den fysiske afstand imellem dem.

Det mellemste led hos Grundtvig, Åndens og Ordets enhed, er også sig selv lig efter at have afstedkommet Guds Riges tilstedeværelse ved, at de er "Giæster ved Hans Naadebord" og derved giver "Guds Menighed" en ny fremtid som menneskelig forsamling.

\section{Sammenfatning, str. 1}

Strofen bruger samspillet mellem kendte udtryk fra Bibelen, samlet om måltidet, som middel til $i$ et enkelt billede at videregive digterens syn på den fælles kristne eksistens. Betegnelsen Guds Rige viser, at den ses som den autentiske menneskelige virkelighed, og at denne har ekstern oprindelse i forhold til den erfarbare tilværelse. Samspillet er præget af en næsten svævende balance mellem de enkelte deltagere, så at billedet åbner sig for en nærmere uddybelse af dets anliggende. Navnlig når "Giæster" ses som verbum activum, bidrager glosen med et moment af det udefra kommende, som tilfører billedet noget nyt, der endnu ikke er fuldt ud realiseret. Strofen virker også som et foran- 
stående resumé af den følgende, bredere udfoldelse af emnet gennem resten af salmen, der ligesom str. 1 er tydeligt tredelt.

\section{Tekstens hoveddel}

Enkeltheder $i$ str. 2-4

\section{Oplæg}

De tre strofer udtrykker en forståelse af Guds Rige, der er bestemt af Bibelen og af Luthers teologi bag om ortodoksi, pietisme og oplysning. Der er sproglige mindelser om pietismen og naturligvis præg af digterens egenart.

\section{Guds Riges manglende synlighed}

Som Guds Riges manglende synlighed omtales i str. 2, kan den føres tilbage til Luk 17,20-21: "Guds rige kommer ikke, så at man kan iagttage det; man vil heller ikke kunne sige: 'Se, hér er det!' eller: 'Se, dér! For Guds rige er midt iblandt jer" (AO 1992; 1817: "inden i Eder"). Dette udsagn kombineres i strofen med Paulus' holdning i diskussionen om spiseregler i Rom 14, 17: "Guds rige er ikke mad og drikke, men retfærdighed, fred og glæde i Helligånden”:

Synligt ei er her tilstæde

Det med Guds Retfærdighed,

Med Guds Fred og Herrens Glæde,

Kommet til os ovenned.

(GSV IV, str. 2, 344)

Kombinationen af de to skriftsteder medfører en egenartet spænding $\mathrm{i}$ forhold til vores velkendte hverdag. I den er håndgribelige udtryk for retfærdighed, fred og glæde påkrævede $\mathrm{i}$ form af et ordnet samfund med retssikkerhed, med fravær af krig, oprør og anden voldsudøvelse og med overskuelige arbejdsforhold og plads til uforstyrret at kunne fejre familiebegivenheder, nationale festdage og årets gang som de ideelle, men sjældent opnåelige vilkår.

Hvad Guds Rige angår, er det ikke umiddelbart sammenfaldende med nogen håndgribelig hændelse. Nogle få eller måske rigtigt mange mennesker kan på forskellig vis udtrykke deres overbevisning om, at de færdes i det rige, eller at det findes inden i dem. Når vi for eksempel holder offentlige gudstjenester eller beder bordbøn, morgenog/eller aftenbøn i familien eller på en eller anden måde prøver at læse os frem til, hvad Bibelen siger om Jesus fra Nazareth og hans baggrund $i$ jødefolket, er det ganske vist synligt $i$ en videre eller snævrere forstand og en eftervirkning af, at vi har hørt og fortsat ønsker at høre 
evangeliet. Disse tilkendegivelser er blot ikke identiske med selve Guds Rige. Det forhold er en anderledeshed ved Guds Rige i sammenligning med det, vi regner med $\mathrm{i}$ resten af hverdagen, når vi taler om retfærdighed, fred og glæde.

Den anderledeshed træder også frem i bemærkningen om, at Guds Rige er "Kommet til os ovenned". Det vil sige, at det har indfundet sig ud af Guds utilgængelighed. I den hverdag, vi lever i skaberværkets virkelighed, går det virkelige sædvanligvis, men dog ikke altid hånd $\mathrm{i}$ hånd med det synlige. Musik er således virkelig, men er den synlig, selv om man kan se instrumenterne og musikerne og ad elektronisk vej aftegne lydene som kurver på papir? Selv om vi kender usynlig virkelighed, skal vi for det meste alligevel gøres opmærksom på, at der er mere til i virkeligheden end det, der kan ses.

Det gælder i desto højere grad om den virkelighed, der hedder Guds Rige, fordi den aldrig lader sig se, og dens instrumenter er altid tvetydige. De kan altid beskyldes for at være selvcentreret fromhed, utidig selvpromovering eller fordækt kulturimperialisme. Derfor er spørgsmålet om, hvordan dette usynligt virkelige bliver nærværende og vedkommende, stadig åbent.

\section{Tradition og forandring}

Str. 3 taler om, at selv om Guds Rige ikke kan udpeges for synssansen, er der andet, der kan gøre opmærksom på dets virkelighed. Det er den påvirkning, der følger af, at det, der siges om Jesus fra Nazareth, opfattes som personlig tiltale:

Men naar os med Herrens Stemme

Aanden kalder hver især,

Kan vort Hjerte dog fornemme,

At Guds Rige kom os nær;

(GSV IV, str. 3, 345)

I v. 1-2 svarer tankegangen til omtalen af Helligåndens gerning i forklaringen til den tredje artikel i Den apostolske Trosbekendelse hos Luther i Den lille Katekismus: "Helligånden har kaldet mig ved evangeliet" (DDS03, 968). Når Grundtvig formulerer sig mere personligt: "Aanden kalder" "med Herrens Stemme", kan det hænge sammen med hans opposition mod den objektivering, for ikke at sige fundamentalisering af Bibelens ord og til en vis grad af prædikengenren $i$ den skikkelse af dogmatisk korrekt teksttolkning, der havde kendetegnet betydende repræsentanter for den lutherske ortodoksi, men ikke Luther selv. Også opgøret med oplysningstidens krav om, at en selvbærende fornuft kunne og skulle afgøre, hvilke af Bibelens mangfoldige udsagn der var gyldige holdepunkter for troen, det, 
Grundtvig kaldte det eksegetiske pavedømme, kan tænkes at have medvirket til den mere personlige formulering. ${ }^{3}$

Når der i v. 3-4 tales om, at vort hjerte kan "fornemme / At Guds Rige kom os nær", kan det ses som analogi til den negative formulering i Den lille Katekismus: "at jeg ikke af egen fornuft eller kraft kan tro". Den har ikke tilfredsstillet digteren, selv om teologen har anerkendt den. Den fanger nemlig ikke den umiddelbare reaktion: "Aha! Her er noget virkeligt og væsentligt på færde", når det mundtlige udsagn markerer nærhedsformen for det Guds Rige, der er midt iblandt os uden at være synligt. ${ }^{4}$ Det gør det vanskeligt at se "fornemme" som udtryk for en indre, vag anelse. Ordet passer bedre som led i Grundtvigs syn på, hvordan vi får et reelt kendskab til den verden, vi lever i. Han mener, at det kendskab indbefatter brugen af "Haand-Følelsen", der mærker tingene. Selv det lille barn rører ved dem og opfatter på den måde, at de er til. Barnet fornemmer dem. De påvirker dets følesans. Senere bringer "den sunde Menneske-Forstand" en vis orden i tingene og gør det desuden muligt at tage stilling til egne følelser (Høirup 1950, 141-142). Udsagnet i v. 3-4 er altså i første række en angivelse af, at vi står over for noget, der rummer muligheder. Der tales om mental åbenhed, ikke om usikkerhed eller om psykologisk sensibilitet.

\section{Baggrund i Bibelen}

Sammen med det semikolon, der afslutter str. 3, markerer det indledende "Og" i str. 4 en kontinuitet, der fastholder, at Guds riges nærværsform knytter sig til taleevnen og høresansen, ikke til synet. Følgen heraf beskrives med et tilsyneladende ejendommeligt skift til smagssansen:

Og naar vi med Tro modtage

Ord og Aand i Jesu Navn,

Rigets Frugt vi forud smage

I det søde Frelsernavn.

(GSV IV, str. 4, 345)

Udtrykket "med Tro modtage" vokser ud af adskillige beretninger om Jesu møder med mennesker. Nævnes kan officeren i Kapernaum (Matt 8,5-13), Jairus med den syge datter og kvinden med blødningerne (Mark 5,21-33), den taknemmelige samaritaner (Luk 17,11-19) og den blindfødte (Johs 9). I alle fem tilfælde får 'tro' vægt ved at indgå i Jesu direkte tale eller som del af det afsluttende udsagn. Det betegner et umiddelbart, åbent og ureflekteret tillidsforhold over for det, Jesus siger, eller det, der er sagt om ham. Et ord, der lyder, kan imidlertid som bekendt også overhøres i den forstand, at det negligeres. Som svar på tiltale er troen derfor en fri sag, selv om den ikke svæver i luften, 
men er knyttet til den, der siger noget. Det indgår i strofens udsagn gennem fremhævelsen af navnet. Følgende passage fra Johannesprologen, kan ses som strofens mest nærliggende forbillede:

Han kom til sit eget, og hans egne tog ikke imod ham, men alle dem, som tog imod ham, gav han magt

til at blive Guds børn, dem, der tror på hans navn;

de er ikke født af blod,

ikke af køds vilje,

ikke af mands vilje, men af Gud.

Og Ordet blev kød og tog bolig iblandt os, og vi så hans herlighed,

en herlighed, som den Enbårne har den fra Faderen, fuld af nåde og sandhed.

(Johs 1,11-14)

Som i v. 1-2 hos Grundtvig er troen sammen med navnet knyttet til Ordet, knyttet til, at det, der siges om og af Kristus, afgør gudsforholdet, og at dette udsagn accepteres. I v. 3-4 sker der et skift fra tale- og lyttekategorien til smagen. I den nære kontekst er "smage" fremkaldt af Rigets frugt og som rim på "modtage", men det korresponderer også med brugen af "Giæster" som verbum activum i betydningen 'bespiser' og medfører, at "Naade-Bordet" fra str. 1 via bespisningsaspektet stadig er til stede. Principielt er "smage" bibelsk sprogbrug, der går tilbage til Sl 34, 9: "Smag, og se at Herren er god". 1 Pet 2,3, citerer stedet, og Hebr 6,5, kan være inspireret af det. I Matt 16,28, og Hebr 2,9, bruges det negativt om at smage døden. Der er således klart tale om metaforisk brug, også når det er Rigets frugt, der smages. Derved rummer linjerne en analogi til skiftet i sansekategori i Johs 1,14 , hvor "vi så" træder ind i Ordets sfære i betydningen 'vi fik blik for', ikke 'vi fik øje på'. ${ }^{6}$ Hele strofen fremstår i det lys som et resumé af afsnittet fra Johs, dog uden momentet af afvisning over for Ordet $\mathrm{i}$ den indledende passus. ${ }^{7}$

Udtrykket "Rigets Frugt" og beskrivelsen i str. 2, v. 2-3 og i str. 67 af Rigets nærværsform som retfærdighed, fred og glæde henleder opmærksomheden på to inspirationskilder. Den ene, Rom 14,17, ses i str. 2. Den anden er Gal 5,22, hvor Paulus i forbindelse med spørgsmålet om at arve Guds rige siger: "Åndens frugt er kærlighed, fred, glæde, tålmodighed, venlighed, godhed, trofasthed, mildhed og selvbeherskelse", altså en lang række ord om frie handlemuligheder. ${ }^{8}$ Det fælles $\mathrm{i}$ de to inspirationskilder gør det nærliggende at identificere Rigets frugt og Åndens frugt. Den formelle fremadrettethed i "forud", der foregriber næringen fra Rigets frugt, og det forhold, at Jesu navn i 
overensstemmelse med Matt 1,1,21: "du skal give ham navnet Jesus, for han skal frelse sit folk fra dets synder", rummer et befrielsesmotiv, udtrykker en åbenhed, som understøttes af, at frelsernavnet er "sødt". Grundtvig bruger gentagne gange denne glose som modpol til alt ufrit i tilværelsen. Det giver den et særpræget befrielsespotentiale. ${ }^{9}$ Sammen med strofens strukturelle og indholdsmæssige åbenhed fastholder denne betegnelse den dynamiske opfattelse af Guds Rige.

\section{Sammenfatning, str. 2-4}

De tre strofer angiver et mønster for, hvordan Guds Rige lader sig erkende, når det ikke fremstår som synligt fænomen. Det sker ved at samle opmærksomheden om meddelelsens form frem for dens indhold, skønt det af str. 2 fremgår, at vi står over for to sider af samme sag. I str. 3 drejer det sig om meddelelsens afsender, i str. 4 om dens modtager. Begge strofer tager udgangspunkt i velkendte formuleringer fra den kristne overlevering og kombinerer dem med erkendeverber, der i sammenhængen bedst forstås ud fra digterens særlige syn på, hvordan mennesket får kendskab til den verden vi lever i. Sammen med den midlertidige suspension af interessen for meddelelsens indhold tilfører dette balanceforhold mellem fælles traditionel terminologi og personlig selvstændig tænkemåde stroferne en åbenhed, der viser, at der er mere at sige.

Enkeltheder i str. 5-6

\section{Oplæg}

De to strofer supplerer den hidtidige beskrivelse af Guds Riges egenart gennem en mere indholdsorienteret udtryksform, der karakteriseres ved, at retfærdighed, fred og glæde, Rigets tre egenskaber fra Rom 14,17, sættes i spil gennem formuleringer, som refererer til syn, hørelse og følesans.

\section{To slags retfærdighed $\mathrm{og}$ freden som gåde}

Str. 5 tilordner de to bestemmelser Guds Retfærdighed og Guds Fred til hver sin sans. Retfærdigheden optræder som subjekt for synssansen i Guds iagttagelse af mennesket, mens Guds Fred er objekt for en elementær, men ikke umiddelbart forklarlig sansning fra menneskets side:

Guds Retfærdighed i Naade

Seer til os fra Himlen ned,

Og skiønt os det er en Gaade, 
Smager Hjertet dog Guds Fred.

(GSV IV, str. 5, 345)

Udtrykket "Guds Retfærdighed i Naade" vinder i dybde, når det sættes $i$ en bestemt sammenhæng hos Grundtvig. Da en ny salmebog blev forberedt i 1840 'erne, bearbejdede han to salmer fra reformationstiden. Den ene var Luthers "Nun freut euch lieben Christen gmeyn" (WA 422, her efter $A M$ III, 437-438), der blev til "Frisk op du ChristenMenighed" (GSV IV, 95-97, jf. DDS03 487: "Nu fryde sig hver kristenmand"). Den anden var Speratus' "Es ist das heyl uns kommen her" (Tekst $A M$ II, 91-92), der blev til "Guds Søn kom ned fra Himmerig" (GSV IV, 92-94, jf. DDS03 488). Næsten samtidig skrev han "Gud Herren saae til Jorden ned" (GSV IV, 106-108, jf. DDS03 498). De tre salmer handler hver på sin måde om genoprettelsen af forholdet mellem Gud og mennesker gennem Kristi komme.

I Grundtvigs "Midt iblandt os" kan de to første strofer resumeres således: "Guds retfærdighed i vrede / så til jord fra himlen ned", mens str. 5-6 kan ses som resume af resten af salmen fra 1845. Det er imponerende, så enkelt og ligetil det indholdstunge, omfattende og dybtgående materiale bringes i spil i disse otte, korte linjer.

I begge tekster er retfærdigheden spændt ud mellem et eksternt forankringsgrundlag og den menneskelige tilværelse. I 1845 beskrives der en afstand mellem de to poler. Gud må lede om, det vil sige søge efter, retfærdigheden. Den er blevet væk. Det viser sig ved, at der ikke kun er langt mellem Gud og hans mennesker, men også langt mennesker imellem. Muligheden for at "ophøie" sig - altså gøre sig til adelsmand på sine medmenneskers bekostning på trods af Jesu ord ved selve det måltid, hvor nadveren blev indstiftet, at "den ældste blandt jer skal være som den yngste, og lederen som den, der tjener" (Luk 22,24-27) - ses i øjnene:

Thi stod jeg som en Synder her,

Min Skaber, for dit Øie,

Om end for Verden reen og skiær,

Jeg turde mig ophøie;

Men ak, jeg veed ei heller Tal

Paa mine Feil og mine Fald,

De dunkle med de klare.

(GSV IV, str. 2, 106-107)

I 1853 overvindes afstanden ved, at der med de ganske enkle udtryk i v. 1-2 etableres et nærvær mellem de to poler: "Guds Retfærdighed i Naade / Seer til os fra Himlen ned", hvor "Seer til os" ophæver afstanden både til Gud og mellem mennesker. Det sidste udtrykkes på anden måde i salmen "Vær du høilovet og velsignet", 1845 (GSV IV, 110 ), der efter placeringen i $G S V$ må være nogenlunde samtidig med 
"Gud Herren saae" og har omkvædet "Kiærligheds Vidunder". Str. 4 rummer bønnen:

Gavmildhed din i al sin Fylde

Skærpe os ind hvad dig vi skylde!

Broder-Kiærlighedens Ild

Blusse faurt og brænde mild!

Kiærligheds Vidunder!

Retfærdighedsmotivet i "Midt iblandt os" er i str. 5 desuden knyttet sammen med gæstemotivet fra str. 1 gennem "Seer til os", som ikke handler om at iagttage vurderende på afstand, men er fyldt med den omhu og opmuntring, der viser sig i vendinger som: "Vi skal hen og se til mormor og morfar".

Gæstemotivets omsorg gemmer sig også i v. 3-4, hvor Guds fred indfinder sig sådan, at "Hjertet" "smager" den. Kombinationen af besøgsaspektet i "Seer til" og måltidsallusionen i "Smager" lader sig uden vanskelighed se som en reminiscens af Åndens og Ordets fælles virke ved Guds "Naadebord", der altså ikke er ganske glemt. På den baggrund fremstår freden ligefrem som noget fysisk mærkbart i menneskesindets dybeste lag, sådan som det mærkes at få mad i munden, når vi er sultne, og sådan som barnet "fornemmer", når det løftes op til sin mors bryst. Der er således ikke tale om gourmeters og vinologers bevidste brug af smagsløgenes distinktionskapacitet eller den følelsesfulde oplæsers smagen på ordene, men om en betydning på linje med den, glosen har i str. 4. Det er os en gåde, at det sker, og sker på den måde. Vi kan ikke selv finde på det eller finde ud af det; det indtræffer bare eller præsenteres for os. Gåden gemmer derfor i sig det moment, at Guds fred findes og kan opfattes trods de håndgribelige fænomener, der daglig truer den, som for eksempel vores gentagne fejlhandlinger og vores gru for døden, i Grundtvigs tilfælde nok især det sidste. ${ }^{10}$

Både retfærdighed og fred ses altså i salmens sammenhæng som indgribende og frigørende drivkræfter, der kommer udefra, giver os et skub og sætter os i gang. For fredens vedkommende kan man som inspiration til denne forståelse tænke på Johs 14, som efter Jesu løfte:

Fred efterlader jeg jer, min fred giver jeg jer.

giver jer ikke, som verden giver.

hjerte må ikke være forfærdet

og ikke være modløst.

(Johs 14, 27)

slutter med hans ord: "Rejs jer, lad os gå herfra" (Johs 14,31).

På baggrund af Grundtvigs indsigt i Det gamle Testamente må der også tages hensyn til det hebraiske 'shalom', som traditionelt oversæt- 
tes ved 'fred' og rummer et dynamisk element: "Grundbetydningen i Ordet er Helhed; det betegner Sjoelenes uhcemmede, frie Udfoldelse. Men dette betyder det samme som harmonisk Fællesskab; Sjælen kan kun udfolde sig i Forbindelse med andre Sjæle" (Pedersen 1920, 201; min kursivering).

\section{Røst, virkelighed og glæde}

Med tilbagevending til tale/høre-kategorien beskrives glæden i str. 6 som indholdet af englens budskab om Jesu fødsel julenat, og dens konsekvens, når budskabet høres, tegnes i billedet af strømmende vand:

Og naar Herrens Fødsels-Glæde

Raabes ud med Engle-Røst,

Virkelig den er tilstæde,

Giennemstrømmer os med Lyst.

(GSVIV, str. 6, 345)

I forbindelse med skiftet tilbage til hørelsen som menneskeligt berøringspunkt tilføres talen om Guds Riges egenart som glæde en ganske betragtelig billedkraft ved, at fortællingen om Frelserens fødsel inddrages. Derved forankres glæden også afgørende uden for os selv samtidig med, at den skaffer sig plads i menneskets verden gennem inkarnationens under. Udtryksformen er ekspansivt dynamisk, som når en meddelelse fra kongen gennem heroldens højlydte råb når ud til hele folket og påvirker det. Samtidig påkalder den som "FødselsGlæde" den skrøbelige sitren, der uvilkårligt griber de berørte, når et barn er kommet til verden. Et fint udtryk herfor hos Grundtvig selv findes i den julesalme, "Deilig er den Himmel blaa", han samme år, som "Midt iblandt os" kom til verden, dannede af strofer fra digtet "De Vise fra Østen", 1810 (GSV II, 197-200):

Der kun sad en fattig Kone,

Vugged Barnet i sit Skiød.

(GSVIV, str. 5, 401)

Når det i "Midt iblandt os" efter henvisningen til julebudskabet i v. 1-2 hedder i v. 3, at glæden "virkelig" er til stede, kan det uden større besvær ses som en afsmitning fra det forhold, at glæden hos Grundtvig ikke alene knytter sig til julen, men også, og især, til nadveren, som det fremgår af treklangene forkyndelse/dåb/nadver; retfærdighed /fred/glæde. ${ }^{11}$ Den virkelige tilstedeværelse svarer til klassisk teologisk tale om realpræsensen, forsøget på at sætte den Opstandnes forkyndte personlige nærvær i nadveren med dens brød og vin på systematisk læremæssig form.

Om "virkelig" gælder det desuden, at glosen er i familie med ord som virke, virksom og virkning. Derfor er der fremdrift i den glæde, 
der virkelig er til stede. Så lidt som den retfærdighed, der "seer til os", og den fred, vi "smager", er glæden, der "råbes ud", et stillestående fortagende. Den er ikke en gang lænestolshygge med kaffe, cognac og indforstået passiar, selv om også det har sin gode plads i menneskers tilværelse. "Herrens Fødsels-Glæde" har en virkekraft i sig, som gør, at den færdes mellem mennesker og i mennesker og bevæger dem. Den "Giennemstrømmer os med Lyst", den himmelske glædes jordiske modstykke. Den gør sig gældende som bækken, der giver grokraft til engens blomster og græs.

Måden, glædens strømning skal opfattes på, kan overvejes. Den udadvendte opstemthed, der fremkaldes i en festlig gudstjeneste med tæt pakket kirkerum og fuldtonende salmesang, kan ses som en mulighed. Da Grundtvig imidlertid kendte og anerkendte også menneskelivets sarte sider, som det ses i "Gudsbarnets Vuggevise", må det kunne gå an også at omtale Martin A. Hansens beskrivelse af at have været til alters en almindelig, tyndt besat søndag i Rorup eller Glim: "Så gik man ud. Dagen var anderledes. Ikke meget. Kun som en dråbe af noget stærkt i et glas vand" (citeret efter hukommelsen). Det ene udelukker ikke det andet.

Dermed er dog ikke alt sagt. Grundtvigs "os" er menigheden. For ham er den ikke en social konstruktion, endsige et konglomerat af enkeltpersoner. Den er i første række et historisk forekommende fællesskab, der skylder virkekraften i forkyndelse, dåb og nadver sin eksistens. Derfor hører det med, at "Herrens Fødsels-Glæde" "Giennemstrømmer os med Lyst" ved at vandre gennem slægtleddene. Det fremgår af det karakteristiske samspil mellem den evangeliske fortælling og menighedens skiftende vilkår i salmen "Herren han har besøgt sit Folk", 1837 (GSV I, 81-84), der ved en omarbejdelse i 1853 forenkles og făr en ny slutstrofe, hvor både centrum i forkyndelsen om Jesus og menighedens lange historie fra Pinsedag til den aktuelle afsyngning af salmen er til stede i fire korte linjer:

Frelseren laae i sorten Jord,

Sidder paa Ærens Throne,

Aand og Liv er for os hans Ord,

Glæden vor Psalme-Tone!

(GSV II, str. 9, 383-384; VI/1, sp. 1, 177)

Den sociale side af glædens dynamik, der minder meget om Johs. Pedersens ovenfor anførte bestemmelse af betydningen af 'shalom', finder vi i den velkendte morgensalme "Morgenstund / Har Guld i Mund", 1853 (GSV IV, 337-338), hvor den forekommer i koblingen mellem str. 3 og str. 4 :

Morgenstund,

Har Guld i Mund, 
Og Guld betyder Glæde, Og glædelig er hver en Dag, Som leves til Guds Velbehag, Om end vi maatte græde!

Gaae da frit, Enhver til sit, Og stole paa Guds Naade!

Da faaer vi Lyst og Lykke til At giøre Gavn, som Gud det vil, Paa allerbedste Maade!

Her samles hver eneste hverdags slid og slæb og deres følger under glædens vinger, fordi Guds nåde gælder. "Midt iblandt os er Guds Rige".

\section{Sammenfatning, str. 5-6}

Stroferne præciserer den mere indholdsbestemte omtale af Guds Rige ved at spænde beskrivelsen af det i bestemmelserne Guds retfærdighed, Guds fred og Herrens glæde op mellem et eksternt udgangspunkt og indvirkningen i og mellem mennesker. Da disse udtryk for Guds Rige rummer momenter af omhu, næring og opmuntring, ses de som integrerede helheder, der omfatter både menneskets individualitet og dets indfældethed i historie og samfund, og der medtænkes igangsættende elementer. Guds Rige forstået som den autentiske mennesketilværelses nærværsform er derfor også i denne mere indholdsprægede form kendetegnet ved en fremadrettethed, der forhindrer det fastlåste, uden at den bliver påtrængende.

Enkeltheder i str. 7-9

\section{Oplæg}

Den bevægelse, der går gennem hele salmen, markeres i disse strofer ved, at slutlinjerne konsekvent henviser til 'det himmelske'. Derved fastholdes fremdriften, og i sidste strofe medfører det, at bevægelsens fornyende åbenhed er helt bestemmende i det sidste udsagns direkte opløftende karakter.

\section{Blomst og frugt}

Str. 7 bruger et kendt og umiddelbart iagttageligt billede fra naturen til kort at sammenfatte væsentlige elementer fra salmen. Samtidig rummer billedet som nyt moment henvisningen til en kommende bekræftelse af Guds Riges indhold. 
Blomstre op da skal Guds Rige

Midt iblandt os Dag fra Dag,

Bære Aandens Frugt tillige,

Fader vor til Velbehag.

(GSV IV, str. 7, 345)

Guds Riges nærvær præsenteres med det særpræg, at blomstring og frugt ikke blot følger efter hinanden, sådan som erfaringen viser, men de følges $a d$, som det fremgår af "tillige", der angiver den ubrydelige enhed af frugt og blomst. Der er ikke plads til mellemliggende fænomener som tid, tørke og uvejr, der kan hindre høsten. ${ }^{12}$ Det bibelske forlæg er antagelig Am 9, 13:

Der skal komme dage, siger Herren,

da den, som pløjer,

følger lige efter den, som høster,

den, som træder persen,

lige efter den, som sår;

bjergene drypper med most,

alle højene driver af væde.

Også overraskelsesmotivet "Af sig selv giver jorden afgrøde" fra lignelsen med kornet, der gror og sætter kerne, mens bonden "sover og står op", kan være tænkt med (Mark 4,26-29). Integreringen af vækst og udbytte er på alle måder lige så gennemført som mellem “Aand" og "Ord" i str. 1. Her i str. 7 svarer den til koblingen af tilliden til Gud med løftet om, at vi får "Lyst og Lykke til / At giøre Gavn, som Gud det vil" i "Morgenstund / Har Guld i Mund" (GSV IV, str. 3-4, 338). Da Guds Riges opblomstring og fremkomsten af Åndens frugt således er to sider af samme sag, bekræftes det, at "Rigets Frugt" fra Rom 14, 17, i str. 4 gemmer en hentydning til "Aandens Frugt" fra Gal 5, 22, i str 7.

Strofens sidste linje henviser til Rom 14,18, om, at den, der tjener Kristus i retfærdighed, fred og glæde, "er velbehagelig for Gud", som oversættelsen lød på Grundtvigs tid. Det svarer til situationen for fårene i lignelsen om Verdensdommen (Matt 25,31-40), der ikke selv har observeret deres egen fortræffelighed, men alligevel tiltales: "Kom, I som er min Faders velsignede". Sammen med talen om, at frugten er Åndens frugt, fastholder det, at "Guds Rige" "Midt iblandt os" ud over at være usynligt også er forankret uden for os.

Selv om strofen ender roligt, er dens udsagn stadig åbent. Vi er i denne verden ikke hjemfaldne til egne evner og forgodtbefindende, men til Guds Riges muligheder. Det fremgår yderligere af næste strofe, der indledes med et begrundende "Thi". 


\section{"... den gode Jord ..."}

Str. 8 præciserer Guds Riges indhold og formål ved at indlejre naturbilledet fra str. $7 \mathrm{i}$ forestillingen om Gud som have-, vingårds- og godsejer, der griber ind over for mennesket som gartner, forpagter eller forvalter:

Thi den gode Jord hernede:

Tro og Haab og Kiærlighed, Rense vil Gud selv og frede Til en himmelsk Frugtbarhed! (GSV IV, str. 8, 345)

Billedsproget i strofen er mest sandsynligt inspireret af modsætningen mellem lignelsen om den ødsle sædemand (Matt 13,4-9par), hvor den gode jord omtales, og "Sangen om vingården" (Es 5,1-6). Hvor sædemandens udbytte på den gode jord er aldeles overvældende, er det gået helt galt i vingården. Den retfærdighed, som står først i rækken af Guds Riges kendetegn i Rom 14,17, er den helt store mangelvare i vingården, der ikke er blevet renset og fredet af forpagteren, og som derfor forfalder fuldstændigt. Med Guds Riges komme er der rejst et nyt havegærde, og der tages fat på ukrudtet. ${ }^{13}$

Rensningen og fredningen ses derfor naturligst som formålet med Åndens og Ordets sammenfaldende virke i menigheden, som det omtales i str. 1, v. 2. Drivkraften i strofen er den tredje linje, hvor grundleddet "Gud selv" henviser til, at det netop er Guds egen bevidste handlen, der er årsag til, at den gode jord kan blomstre og bære frugt. $\mathrm{Nu}$ er der ikke længere svigefulde forpagtere mellem ham og vingården (Es 5,1-5; Matt 21,33-41). Der er ingen troløse godsforvaltere, der rager til sig af høstudbyttet (Luk 16,1-8). Der er ingen havemand, som sammen med sin kone totalt misforstår sin opgave (1 Mos 2,8;3,1-13).

Der er grund til at mærke sig det kolon, der står efter "den gode Jord hernede", og som medfører, at "Tro og Haab og Kiærlighed" er en nærmere bestemmelse af den jord, der skal renses og fredes. Jorden er for Grundtvig Guds skaberværk. De tre fænomener er derfor ikke selvberoende fortræffelige egenskaber hos os mennesker. Troens "Himmel-Stige" går fra Gud 'ned' til os, ikke fra os 'op' til Gud (GSV V, 449-451. Uffe Hansen III, 317-319). "Herlighedens Haab" er Guds særlige dåbsgave (GSV III, str. 3, 508). Kcerligheden i sin endegyldige form kommer med Jesu virke som Frelser:

Du mig elsket har til Døden,

Og endnu mig elsker saa,

Daler med din Kiærlighed

Til mit Hjerte ydmyg ned, $($ GSV IV; str. 5, 301) 
De "Tre" (GSV I, str. 1, 228) er at se som evige gaver i Guds skaberværk, hvorom det hedder: "Gud så alt, hvad han havde skabt, og han så, hvor godt det var" (1 Mos 1,31a). "Så bliver da tro, håb, kærlighed, disse tre" (1 Kor 13,13a). Det er, når vi ser dem som vore egne, fortræffelige evner, det går galt, så Gud selv må genoprette sin gode skabning. Det er derfor, Adam som gartneren, der går fejl af sin opgave, og forpagteren og forvalteren, der bryder kontrakten, må medtænkes i strofen om "den gode Jord hernede".

Det kan meget vel tænkes, at Grundtvig i sin behandling af denne dobbelthed ved den gode jord har fåt inspiration fra slutstrofen $\mathrm{i}$ Kingos salme om den ødsle sædemand. Salmen er som nr. 5 med i Fenger og blev optaget i $R$ i 1856, så Grundtvig har kendt den som en af de Kingo-salmer, der måtte med i salmebogsfornyelsen efter massakren med $E$. Kingos strofe lyder:

For Torn og haarde Steene

Min Hierte-Grund befrj.

Hegn mig med Naadens Greene

Fra Verdens Synde-stj!

Dyrk selv mit Hiertes Ager,

Dend Frugt maa bære saa,

Som det Dig, Gud, behager,

Til Ærens Krands at naa.

(KSS IV, str. 6, 266)

Der er nøje overensstemmelse mellem "rense" og "frede" hos Grundtvig og de første fire linjer i Kingos strofe. "mit Hiertes Ager" hos Kingo skal bære frugt, "Som det Dig, Gud, behager", sådan som "den gode Jord hernede" gør det "Fader vor til Velbehag" hos Grundtvig. Det, Kingo beder om, ser Grundtvig som sat i værk, men Kingos bøn lyder på baggrund af, at Gud allerede er i gang med at sprede sit ord "I Folke-Hierters Jord" (KSS IV, str. 1, 264), så forskellen ligger i de to salmers forskellige måde at udsige den samme sag på: det er Gud selv, der genopretter den skete skade, menneskets handle- og væremåde $\mathrm{i}$ skaberværket er udtryk for. ${ }^{15}$

Når der i sidste linje af Grundtvigs strofe tales om, at den resulterende frugtbarhed er "himmelsk", må meningen være, at frugtbarheden ikke lader sig se på de vilkår, vi lever under nu, og vi kan derfor ikke tage æren af den. Det svarer til, at "Ærens Krands" hos Kingo ikke opnås ud fra, hvad der er ærefuldt i vore øjne, men ud fra "det Dig, Gud, behager". Igen kan man tænke på, hvor overraskede fårene bliver hos Matthæus (Matt 25,37-39).

Strofens opmuntrende udsagn fastholder temaet om Guds Riges usynlighed som et værn mod, at vi låser os fast $\mathrm{i}$ egen moralitet og målrettethed. Samtidig beholder den salmens på én gang eftertænk- 
somme og fremadrettede grundstemning ved at bruge motivet Skabelse og Genløsning, som viser sig ved, at midlet til at hele bruddet mellem Gud og menneske er, at Gud selv vil rense og frede "den gode Jord".

\section{Forklaring; genfødsel; tilsynekomst "i Sky"}

Den fremdrift i salmen, som har været båret af et spændingsdrevet samspil mellem enkeltudsagnene, føres i slutstrofen frem til et højdepunkt, der lader en befriende afklaring frem for en fastlæggende afslutning stå som det endegyldige udsagn om Guds Rige:

Og naar vi med ham forklares,

Som os fødte her paany,

Skal Guds Rige aabenbares,

Synlig som han selv i Sky!

(GSV IV, str. 9, 345)

Strofens hovedperson introduceres som handlende væsen. Han er den, "Som os fødte her paany". Talen om hans komme "i Sky" bekræfter, at det drejer sig om Kristus (Mark 13,26). Når salmen bruges ved en gudstjeneste, føres tanken hen på dåben, fordi genfødslen nævnes. 1 Pet 1,3, hvor glosen bruges, citeres i dåbsritualet både på Grundtvigs tid og i vore dage, $\mathrm{i}$ begge tilfælde på en fremtrædende, men forskellig plads (Thodberg 1989, 17. DDS03, 825).

Tanken om Kristus som den fødende belyses af salmen "Kom, følg i Aanden med", 1853 og 1864 (GSV II, 208-210; V, 504-505). Den er i sin oprindelige form fra samme år som "Midt iblandt os", og begge salmer bliver trykt første gang i Festsalmer, 5. opl. (GSV VI/2, 150; 335). I "Kom, følg”, str. 7-8, sammenskrives Johannes' dåb og den kristne dåb, altså Jesu dåb og vores dåb, i ét sammenhængende forløb. Det sker gennem mellembestemmelsen "Daab med Helligaanden", der dels henviser til fortællingen om Jesu dåb, der nævner Åndens tilsynekomst "ligesom en due" (Matt 3,16), dels til fortællingen om den første dåb i menigheden på Pinsedag, hvor Helligånden optræder som "et fremfarende vældigt Væir" og viser sig for de tilstedeværende i skikkelse af "Tunger som af Ild" (ApG 2,2-34, $A O$ 1817), og endelig til ritualets ord, at den døbte er "genfødt ved vand og Helligånden" (Thodberg 1989 17, pkt. 11. DDS03, 828).

Den kristne dåb benævnes også "Vorherres Daab / Til Herlighedens Haab" (GSV II, str. 8, 210; 1864: "Gudsaandens Daab", GSV $\mathrm{V}$, str. 8, 505). Det er i overensstemmelse med adskillige andre, lignende udtryk i Grundtvigs salmer (Thodberg 1989, 68-87), helt tydeligt i linjerne fra hyldestsalmen til Kristus "Lov og Tak og evig Ære”, 1843: 
Lov og Tak og evig Ære

For din Røst, som, i vor Daab,

Kalder os Guds Børn, de kiære,

Skiænker Herlighedens Haab;

(GSV III, str. 3, 508)

Sammentænkningen af Jesu dåb og vores dåb ved hjælp af begrebet 'dåb med Helligånden' viser, at den kristne dåb bliver til ved, at Johannes-dåben omdannes, da Jesus lader sig døbe med den. Det svarer til, at jødernes mindemåltid for udfrielsen fra Ægypten bliver til den kristne nadver, fordi Jesus identificerer brød og vin med sig selv (Matt 26,26-29. Jf. Johs 6,47-51; 1 Kor 11,23-26). ${ }^{16}$

Den genfødsel, Kristus sætter i værk, har som følge, at "vi med ham forklares". Hørt ud fra hverdagssproget betyder det, at når vi er sammen med ham, viser det sig, hvem vi egentlig er. Kun i den situation falder det lys over os, som gør, at vi til bunds kan se os selv og forstå os selv. Her i salmen henter "forklares" derudover indhold fra fortællingen om "Jesu forklarelse på bjerget", hvor en lysende sky som tegn på Guds nærvær tilhyller ham (Matt 17,1-5). I den fortælling hører Peter, Jakob og Johannes som bekendt en stemme, der siger de samme ord, som lyder i beretningen om Jesu dåb: "Det er min elskede søn, i ham har jeg fundet velbehag" (Matt 3,16-17). Når Kristus kommer "i Sky", skal det altså ses, at disse ord er sande, og at de gennem genfødslen i dåben også gælder de døbte, der "med Tro modtage / Ord og Aand i Jesu Navn" og derved får forsmag på "Rigets Frugt" ("Midt iblandt os", str. 4). ${ }^{17}$ En side af sagen er foregrebet i str. 7, v. 3-4, med glosen "Velbehag".

Med henblik på betydningen af "forklare" er det igen nyttigt at inddrage indledningen til Nordens Mytologi, 1832. Mennesket ses her som det eneste livsvæsen på jorden, der er bevidst om sin egenart. Det beskrives som "et Guddommeligt Experiment, der viser, hvordan Aand og Støv kan giennemtrænge hinanden, og forklares (min kursiv) i en fælles guddommelig Bevidsthed" (US V, 408), og som en "vidunderlig Gaade" (sstd. 400). Her betegner 'vidunderlig' ikke storslået, pragtfuld eller herlig, men underfuld, mirakuløs, som det ses af modstillingen "Vidunderligst" og "Dets Herlighed" i strofen fra 1853:

Vidunderligst af Alt paa Jord

Er Jesu Christi Rige,

Dets Herlighed er og saa stor,

At det har ingen Lige.

(GSV II, str. 1, 385)

og definitionen i str. 3: "Dets Gaade er et Guddoms-Ord". Se også $O D S$, s.v. vidunderlig, 1), hvor Aladdin og den vidunderlige Lampe citeres som bogtitel fra 1873. Af ydre er denne lampe som bekendt 
gammel og uanselig. "forklares" taler på den baggrund ikke primært om en særlig glans, men om "Gaadens" løsning, "Experimentets" udfald. Søger man et bibelsk forlæg for tankerne i citaterne fra Nordens Mytologi, trænger især 1 Kor 13,12, sig på: "Endnu ser vi i et spejl, i en gåde ( $A O$ 1817: i en mørk Tale), men da skal vi se ansigt til ansigt. $\mathrm{Nu}$ erkender vi stykkevis, men da skal jeg kende fuldt ud, ligesom jeg selv er kendt fuldt ud". 'Forklaring' i betydningen af fjernelse af forstyrrende elementer (herunder mørke) fra synsfeltet og 'fuld erkendelse' er her i høj grad i familie med hinanden, om ikke ligefrem identiske.

Med det ontologiske citat "når vi i ham forklare", hvor der naturligvis henvises til Kristus i skikkelse af den Jesus, der lod sig døbe af Johannes, og som senere tog brødet, takkede og brød det, lader Jesu betydning sig ikke længere drage i tvivl. Så står det klart, at med ham er Guds Rige trådt ind i menneskers liv. Fortællingerne om hans livsskæbne og om hans virke $i$ ord og handling afslører sig som én lang billedrække, der viser os, hvad Guds Riges indhold er, og sætter det ind i vores verden.

Den tolkning af Jesu liv, at i det er Kristi komme og Guds Riges nærvær uadskilleligt tilstede, er ikke ukendt. Man kan tænke på indledningen til forklaringerne af nogle af De ti Bud i Matt 5: "I har hørt (...), men jeg siger jer", og på udsagnet forud for en del af lignelserne: "Med Guds rige er det som med" (Matt 13,44.45.46; Mark 4,26.30). Henvisningen til S1 78,2: "Jeg vil åbne min mund med lignelser, jeg vil fremføre det, der har været skjult siden verden blev grundlagt", peger i samme retning. Også vurderingen af underne som 'tegn' (Johs 20,2031) og bemærkningen: "Men hvis det er ved Guds finger, jeg driver dæmonerne ud, så er Guds rige jo kommet til jer" (Luk 11,20) kan anføres som udtryk for forestillingen om, at Kristi komme og Guds Riges nærvær går $\mathrm{i}$ ét med hinanden $\mathrm{i}$ Jesu liv. Og så må omkalfatringen af Johannes-dåben og påskemåltidet $\mathrm{i}$ fortællingerne herom ikke glemmes.

I strofens og salmens slutlinjer: "Guds Rige aabenbares, / Synlig som han selv i Sky", formuleres ophævelsen af tvivlen om sammenfaldet mellem Kristi komme og Guds Riges nærvær i ét med en præcisering af, hvad dette sammenfald betyder. "I Sky" svarer her til det engelske 'in the sky': på himlen, sådan som sol og måne og stjerner er det. Denne brug af 'i sky' er hyppig hos Grundtvig ( $H B$, 439-440), men forekommer også hos Brorson i betydningen 'op mod himlen' (BSS I, str. 7, 32). Der er ikke gnist af regn eller slud, sne, lyn eller torden tilbage, selv om forlæggene i 1 Thess 4,13-18 og Matt 24,29-40 med deres forløber i Dan 7 forudsætter, at der forud er gået en turbulent periode med en meget stor portion drama. 
Da åbenbaringen af Guds Rige "i Sky" implicerer Kristi synlige komme, indgår også motivet med den dagsordensættende person $\mathrm{i}$ strofen. $\mathrm{Nu}$ er han transformeret fra initiativrig gæst til fællesskabets faste og samlende centralfigur. Ad den vej er "Hans Naadebord" stadig med i billedet som uomtalt korrelat til "Guds Rige". Placeringen af den skyfri himmel i strofens og dermed salmens sidste udsagn tilfører en frigørende åbenhed som det afgørende præg.

Strofen taler i et ukompliceret sprog om et tema, der befinder sig hinsides det erkendelige, og som traditionen benævner Kristi Genkomst. Der er tale om en poetisk form, som på fornem, for ikke at sige genial vis bruger ganske ligefremme og hverdagsagtige gloser, der også forekommer i bibelsk sprogbrug. Det enkle, næsten sarte i udtryksformen for det uudsigelige sætter sit i ordets mangfoldige betydninger og i bedste forstand opløftende præg på salmens sidste ord, der derved udgør en åbning mod noget nyt.

Åbningen mod det uerkendelige lader sig dog stille i forhold til noget iagttageligt: en næsten fysisk lettelse, en rumlig opadstigen, en afklaring i sindet, en eksistentiel forløsning kan nævnes som erfaringselementer, der kan inddrages som referenspunkter for den befrielse, som indtræder gennem den måde, den indbyggede spændstighed $\mathrm{i}$ salmen og dens enkelte afsnit og strofer udløses på i de afsluttende to linjer. Strofen er som vinduet, der mod øst bag alterbordet $i$ en lille romansk kirkes korvæg afslutter rummet, men er åbent helt ud mod solens opgangssted gennem det lys, der om morgenen strømmer ind ad den farvede glasmosaiks afgrænsning mod verden udenfor. ${ }^{18}$

\section{Sammenfatning, str. 7-9}

Slutlinjerne i str. 7-9 er tre forskellige, men konsekvente henvisninger til den autentiske mennesketilværelses eksterne pol: Gud som Far; frugtbarheden som himmelsk; synet ansigt til ansigt. Derved positioneres denne pol som drivkraften i den spænding, som driver det samspil, der går gennem hele salmen, dens afsnit og dens enkelte strofer. De tre strofer er også det højdepunkt, resten af salmen stiler imod, sådan som v. 1-3 i første strofe stiler mod "Hans Naadebord", og de udsiger derigennem den befriende fornyelse på baggrund af vores erfaringer om det vellykkede gæstebuds virkning. Derudfra udtrykker slutstrofen på fornem vis den overbevisning, at tilhørsforholdet til den mennesketilværelse, Jesus fra Nazareth levede og levede ind i vores eksistens, er den autentiske mennesketilværelse, og den ser frem til det øjeblik, da dette bliver klart for alle og enhver. 
Mere hjalp hos japanerne

\section{Oplæg}

Den ubetingede åbenhed, str. 9 udtrykker, og som kan rumme alt fra den helt kortfattede, prosaiske konstatering hos K. L Aastrup til det storslåede, poetiske panorama hos $\mathrm{H}$. A. Brorson (se note 18), rejser det spørgsmål, om strofens udsagn ikke svæver i luften uden hold i virkeligheden trods talen om blomstringen iblandt os i str. 7 og om den gode jord hernede i str. 8. Inden den antagelse gøres til kendsgerning, vil jeg inddrage endnu to haiku. Det sker ud fra den tredeling, som også Grundtvig er glad for, her tredelingen af str. 2-9, og ud fra, at de to japanske digte har en tilsvarende åben afslutning.

\section{Analyse af to haiku}

$\begin{array}{ll}\begin{array}{l}\text { En gammel } \\ \text { Dam }\end{array} & \begin{array}{l}\text { Grønhed } \\ \text { så ung }\end{array} \\ \begin{array}{l}\text { En frø } \\ \text { Springer }\end{array} & \begin{array}{l}\text { Udækket } \\ \text { af blade }\end{array} \\ \text { Plask } & \begin{array}{l}\text { (Alene } \\ \text { bjerget) }\end{array} \\ \text { (Nielsen 1963, 33) } & \text { (Nielsen 1963, 73) }\end{array}$

Den af mig tilføjede parentes markerer, at digteren Busons egen formulering af det tredje afsnit ikke er tekst, men en tegning af en vulkan med snedækket tinde (Nielsen 1963, 184). Gloserne i parentesen er oversætterens/udgiverens verbale formulering af udsagnet.

Som første afsnit i begge haiku forekommer et tilsyneladende uforstyrret og afgrænset naturfænomen. Derpå nævnes et fænomen, som forskyder opfattelsen af det uforstyrrede og afgrænsede. Der sluttes med 'en ny verden', der beskrives med henholdsvis en lyd og et billede, altså uden egentlig sproglig formulering. Digtene er i egentligste forstand billedtale, men er billederne kun billeder af sig selv, svævende i luften? Næppe. Begge digtes digtere digter om 'noget', selv om haiku-digtningens to største mestre må ty til et onomatopoietikon og en tegning for at få sagt, hvad de vil.

Uanset sammenstødet med sprogets grænser siger deres digte noget værdifuldt, betydende, vedkommende. De er mere end ren æstetik.

Bashos digt om dammen nærmer sig en burleske, og vi ved fra "Smeden og Bageren" (Wessel 1784), at en sådan kan rumme mere end det sjove, i dette tilfælde især, hvis man ud fra digtets ironi 
insisterer på absurditeten i dommens præmisser i forhold til tanken om et retssamfund og en meningsfuld tilværelse.

Busons digt minder mere om en idyl, men en sådan kan tale om mere end skønheden og freden. Det kender vi fra "Rungsteds Lyksaligheder" (Ewald 1775), hvor digteren ser idyllen pege hen mod Skaberens storhed og godhed, der er i stand til at omdanne den sorg, digtet dækker over, til en ubegribelig glæde.

Sammenholder man de to haiku, bliver det tydeligere, at de kan læses som udsagn om 'noget'. De henviser begge til en tilstand, der kan låse os fast, over for en tilføjelse, der kan føre os videre. Hvis man ud fra tillægsordene gammel og ung ville knytte forholdet alene til menneskets livsaldre og udelukkende tænke på dem, der besværer sig over alderdommens byrder eller bliver hængende i en livsvarig pubertets sårbarhed, ville man imidlertid komme på tynd is. Der findes jo yderst opmærksomme gamle og aldeles apatiske unge. De to digtes fælles udgangspunkt er en uundgåelig udsathed, som til enhver tid, men på forskellig vis kan sætte livet i stå og til sidst lægge det øde, en udsathed, som ikke lader sig fange i en bestemt formel.

I Bashos digt om den gamle dam møder vi udsatheden i skikkelse af truslen om, at alt forsvinder i sløvhed og sædvane. Dammen er, som den er. Der er ikke noget at gøre. Man er lige ved at tildigte andemadens kvælende tæppe, mens man ikke kan få øje på én eneste and. Død og råddenskab synes at lure lige under overfladen.

Hos Buson er det skønhedens skrøbelighed og det spirende livs udsathed, der aftegnes. Ikke i dramatisk-tragisk form som i Njals Saga, hvor Gunnar fra Hlidarendes berømte replik: "Fager er lien”, fører til hans undergang gennem den fatale beslutning om at blive, selv om hans landsforvisning er tidsbestemt (Larsen 1955, 58). Billedet af udsatheden er hos Buson hentet $\mathrm{i}$ den vemodige erfaring fra naturen selv om, at det nyspirede græs eller korn kan svides af ved blot en enkelt nats frost. "Menneskets liv er som græsset", for nu at citere en anden tradition (S1 103,15).

Sådan som udsatheden ses i to skikkelser, forfald og sårbarhed, har også den perspektivforskydning, der forstyrrer forgængeligheden, som de gamle kaldte det, to ansigter.

Hos Basho er det frøens spring, der afstedkommer det nye syn på dammen. Den frø, der må have været der hele tiden, men først nu fanger opmærksomheden, afslører, at der er en anden virkelighed i tilværelsens gamle dam end apatien.

Hos Buson er den forandrende faktor selve markernes nøgenhed. Den inddrager gennem mindet om de bortblæste blade efterårets løvfald og vinterens kulde. Derved henledes opmærksomheden på, at 
græssets skønhed er ambivalent, ikke kun en fryd for øjet, men også udsat og sårbar. ${ }^{19}$

I sidste afsnit af Bashos digt afsløres det, at der er handling og hændelse til i den tilsyneladende uforanderlige tilværelse. Et i første omgang overset element får dammen til at give lyd fra sig. Den er sat $\mathrm{i}$ bevægelse. Verden er alligevel ikke totalt passiv og stillestående.

Busons digt røber tilsvarende, at skrøbeligheden har en forankring. I det ambivalensskabende perspektiv, markernes nøgenhed fremkalder, åbnes udsigten til, ja, ér det Fujiyama, den japanske nationalhelligdom, Udødelighedens Bjerg?

\section{Sammenligning med salmen}

De to japanske digte fremstår som tegn på papir og kan gengives som lyd i ord, og de har deres virkning som billeder i sindet. Der afsætter de et spændingsfelt mellem to poler. Den ene er beskrivelsen i digtenes to første led af et sammensat fænomen, den anden henvisningen til fænomenets helhed, der så at sige trækkes ind ved hjælp af hvert digts tredje og sidste led, som (af den grund?) befinder sig på grænsen af sprogets udtryksmuligheder. I "Midt iblandt os" opstår et tilsvarende spændingsfelt gennem de tre led, str. 2-9 lader sig inddele $i$.

I str. 2-4 møder vi faren for den stilstand, der kan føre til forfald, fordi de traditionelle udtryk om Guds Rige rummer den sårbarhed, at de kan opfattes som en død ortodoksis stivnede standardfraser. Når Rigets retfærdighed, fred og glæde er usynlige, er de så andet end tom snak? Når vi kaldes af ånden med Herrens stemme, er det så ikke blot besværgelser, der skal give fortællingerne om Jesus et højtideligt præg? Når ord og ånd skal modtages i Jesu navn, tales der så måske om en tilfældig sindsstemning eller grov hjernevask? Denne outrerede formulering af kritikken ville Grundtvig nok stå fremmed over for, men som bekendt købte han ikke de foregående epokers udtryksformer og forståelse af kristendommen ubeset. Sårbarheden hos ortodoksi, pietisme og rationalisme havde han efterhånden fået et skarpt blik for, selv om han kunne være både sen i optrækket og alligevel hovedkulds i sin egen måde at sige tingene på. Verdens Krønike, 1812 (US III, 165-422) og Kirkens Gienmcele, 1825 (US IV, 395-429) er to ypperlige eksempler herpå. Billedligt talt var han opmærksom på, at de kendte ord i str. 2-4 kunne høres, som handlede de om et stillestående vandhul, måske endda overgroet af andemad, og langt fra det sprudlende væld mindst på størrelse med Store Blåkilde øst for Rold Skov (som han næppe kendte), der dukker op i overskriften Livskilden $i$ Daaben til salmen "Alle mine Kilder skal være i dig", 1856-60 (GSV V, 257-258). 
I str. 5-6 sætter han nu de klassiske udtryk $\mathrm{i}$ et andet perspektiv. Retfærdighedens særlige art ses ikke længere som formelle bestemmelser om konsekvenserne af manglende principfasthed hos en skyldig kludremikkel. $\mathrm{Nu}$ tales der om den oprigtige besøgendes indlevede opmærksomhed over for vilkårene i det hus, der gæstes. Sådan er det at færdes ret. På lignende måde skiftes der perspektiv i strofens tale om freden. Risikoen for den overenskomstfastlagte sædvane, der kan føre til stivnen, eller den naive uanfægtethed, der kan føre til principløshed, erstattes af en tilstrømning, der bærer tilblivelse i sig, som det træder frem i talen om, at freden smages. Med talen om fødselsglæden, der råbes ud, endda med englerøst, træder den nye perspektivering også i vejen for en statisk forståelse af Guds Rige. Den sætter bevægelse i os og sætter os i bevægelse. Energien i denne sprogbrug lade sig ikke forene med, at udtrykket "Giennemstrømmer os med Lyst" skulle kunne ses som den private, indre fornemmelse af opstemthed, som børn kan opleve ved synet af juletræet (som Grundtvig vist var skeptisk overfor), når døren åbnes juleaften. Så skal træet jo se ud, som det altid har gjort. Glæden svarer snarere til fryden ved at gå syngende om træet og ved at give og fă gaver. Der er tilskyndelse til bevægelse, ikke til hensynken i betagelse, i talen om "Herrens FødselsGlæde".

Når udsatheden indgår i tilværelsens vilkår og sprogets betingelser (str. 2-4), men Guds Rige forstås som forandrende kraftfelt (str. 5-6), danner den derved opståede fremadrettetheds endemål (str. 7-9) en modpol, der er nødvendig for indholdsbestemmelsen af det billede, digtet danner i sindet. Vi mødte det samme forhold i de to haiku. Lyden og den enlige silhuet af bjerget svæver ikke i luften, lukkede om sig selv og uden anden betydning end den, der kunne dannes af den enkelte lytters eller læsers tilfældige gæt eller vilkårlige skøn. Når dammen og det spirende græs, frøen og markernes nøgenhed optræder forud, bliver lyden og silhuetten meningsgivende modpoler til de andre elementer i billedet. Meningens omrids bestemmes af alle elementer i forening og kan nøjere præciseres af samspillet mellem dem og af flere lyttere og læseres vurdering af og samtale om det, alle har hørt og/eller læst.

\section{Sammenfatning}

De sprogligt fastlagte fænomener i str. 2-4 og perspektivforskydningen i str. 5-6 inddrages i str. 7-9 hos Grundtvig, sådan som dammen og frøen indgår i plasket, og græsset og de manglende blade hører med til bjerget hos japanerne. Synsindtrykket fra de japanske digtes indledende fænomener fra naturen bevares i det afsluttende udsagn af sig selv i læserens bevidsthed. Grundtvig bruger et historisk betinget 
materiale, som må genfortælles for at bevare sit nærvær. Fænomenet fra str. 2-4 resumeres derfor i str. 7, og dynamikken fra str. 5-6 i str. 8, førend str. 9 udsiger afsnittets selvstændighed ved at inddrage noget nyt som meningsgiver $i$ helheden: den åbne skyfri himmel som indholdsbestemmende repræsentation for det autentiske menneskelivs oprindelsessted og endemål. Ved at denne selvstændighed i str. 9 fungerer som medvirkende meningsgiver, træder den frem som en virkelighed, men den refererer ikke som de tilsvarende led hos japanerne til en egenskab ved naturen. Den inddrager et levet menneskeliv, knyttet til en navngiven person, nemlig Jesus fra Nazareth, "Som os fødte her på ny". I salmen har dette menneskeliv samme funktion, virkelighed og virkning, som lydordet og tegningen har det $\mathrm{i}$ de to haiku.

\section{Konklusion}

\section{To illustrationer}

På grund af de påviste spændingsmomenter er salmens udtryk helt igennem fremadrettet $\mathrm{i}$ den forstand, at såvel de enkelte strofer og afsnit som salmen i sin helhed åbner sig mod yderligere udfoldelse af tekstens anliggende.

I forhold til de enkelte strofer medfører spændingen, at deres udsagn sikres mod at blive enten stillestående eller påtrængende. I deres afsluttende linjer falder udtrykket til ro uden at lukke af. Det gælder også slutstrofens sidste linje. Den dynamiske karakter, spændingsmomenterne fremkalder, ligger langt fra den anmassende energi hos supertankere og jetfly, der med overvældende maskinkraft baner sig vej uanset vejr og vind. Den minder mere om svæveflyvernes betingelser, når de roligt glider fra opvind til opvind hen over landskabet, eller vilkårene for de elegante te-clippere, der i sin tid udnyttede de gunstige vinde på deres vej over verdenshavene.

I salmen som helhed er dynamikken modificeret af den meditative tendens, som knytter sig til de åbenlyse henvisninger til og de underforståede antydninger af bibelske tekster og kristen tradition. Derved dannes en art buestruktur, som rækker fra Jesu historie med virkningshistorien efter ham over det lydelige ord, der bærer dem og kalder menneskets tillid frem med de nutidige følger heraf, og frem til et syn mod det uudsigelige. Denne buestrukturs forløb og dynamik lader sig ikke sammenligne med en vandring ad tiltrådte stier, endsige en taktfast march ad fast, banet vej. Den svarer snarere til bækkens rislen gennem skov, mark og eng med fuglenes fløjt ovenover og udsigt til ro i åens glidende løb mod havet, der ved den uendeligt fjerne horisont mødes med himmelen. 
Spændstigheden i kombinationen af spænding og samspil medfører, at selv salmens sidste udsagn ikke har præg af afslutning, men af ny åbenhed. ${ }^{20}$

\section{En sidste hjoelp fra japanerne}

En sammenligning af salmens opbygning med strukturen i eksempler fra japansk haiku-digtning viser, at salmens grundtema, Guds Rige, trods usynligheden ikke lader sig tilsidesætte som et fantasifoster, hvis indhold afhænger af tilfældige ideer eller personlige yndlingsforestillinger. Ud fra sin samlende funktion som uset medspiller i salmens helhed bestemmes Guds Rige som den uantastelige åbenhed og ubetingede befrielse, der træder ind i historien gennem det liv, Jesus fra Nazareth levede. Det ses som viderebragt i historiens løb gennem forkyndelse, dåb og nadver i menigheden med eftervirkninger i det fælles liv og tilegnet af den enkelte gennem troen.

Som indbegrebet af denne frihed og åbenhed iværksætter Guds Rige en sammenhæng mellem inkarnationen, set som en hændelse i historien med frisættende følger i det fælles liv og for den enkeltes tilværelse, og eskatologien, set som en stadigt ny åbenhed over for fremtiden både i kronologisk forstand, 'timeligt', og i eksistentiel betydning, 'evigt'.

\section{Forkortelser}

\section{Bibelen}

AO 1740: Biblia: det er den ganske Hellige Skrifts Bøger (16. opl., 1819), København.

AO 1992: Bibelen. Bibelen. Den hellige skrifts kanoniske bøger, 1992, København.

\section{Grundtvigudgaver}

GSV I-VI: Th. Balslev et al. (udg.) (1944-64), Grundtvigs Sang-Vark. Samlet Udgave, bind 1-6, København.

HGS I-III: Ernst J. Borup og Frederik Schrøder (udg.) (1929-31), Haandbog $i$ Grundtvigs Skrifter, bind 1-3, København.

US I-X: Holger Begtrup (udg.) (1904-09), Nik. Fred. Sev. Grundtvigs Udvalgte Skrifter, bind 1-10, København.

\section{Salmeudgivelser}

Aastrup: K. L. Aastrup (1949), Salmer. Fjerde Samling. København.

BSS I-III: L. J. Koch (udg.) (1951-56), Hans Adolph Brorson. Samlede

Skrifter, bind 1-3, København. 
Fenger: P.A. Fenger (udg.) (1827), Psalmer og aandelige sange af Thomas Kingo, København.

KSS III-IV: Hans Brix et al. (udg.) (1975), Thomas Kingo. Samlede Skrifter, bind 3-4, København.

\section{Salmebøger}

DDS03: Den danske Salmebog, 2003, København.

DSP1921: Den svenska Psalmboken (...) med nya Psalmer, 1921, Stockholm.

E: Evangelisk-kristelig Psalmebog, 1798, København.

R: Psalmebog for Kirke- og Huus-Andagt, 1855, København (Roskilde Konvents salmebog).

$R T$ : Tillæg til $R, 1873$, København.

\section{Håndbøger}

AM I-V: Anders Malling (1962-66), Dansk Salmehistorie. Salmerne, bind 15, København.

$C B$ : C. Berg (1864), Graesk-Dansk Ordbog, København.

DDK03: Den danske Koralbog, 2003, København.

$H B$ : Holger Bennike (1970), Salmeordbog, København.

ODS: Det Danske Sprog- og Litteraturselskab (udg.)(2005-7), Ordbog over det danske Sprog, ODS på nettet, www.ordnet.dk

RB: Rudolf Bultmann (1959), Das Evangelium des Johannes, Göttingen.

\section{Litteraturliste}

\section{Voerker af Grundtvig}

Balslev, Th. et al. (udg.) (1944-64), Grundtvigs Sang-Vark. Samlet Udgave, bind 1-6, København.

Borup, Ernst J. og Schrøder, Frederik (udg.) (1929-31), Haandbog $i$ Grundtvigs Skrifter, bind 1-3, København.

Begtrup, Holger (udg.) (1904-09), Nik. Fred. Sev. Grundtvigs Udvalgte Skrifter, bind 1-10, København.

\section{Voerker af andre forfattere}

\section{Faglitteratur}

Dam, Poul (1999), "Noget om Myterne omkring den Clausens'ske injuriesag og Grundtvigs censurperiodes afslutning", Grundtvig-Studier 1999, København, 7-26.

Engberg-Pedersen, Troels (1994), "Hellenistisk kultur. Videnskab, litteratur, filosofi", VI. Filosofi, Den nytestamentlige tids historie. Dansk kommentar til Det nye Testamente - 2, Aarhus, 97-116.

Ertner, Jørgen (1997), "Et ord af Guds Søn”, Grundtvig-Studier 1997, København, 185-211. 
Hansen, Uffe I-III, (1937-66), Grundtvigs Salmedigtning, bind 1-3, Odense og København.

Holm, Jette (2005 I), "Grundtvigs prædiken i Vartov 1. Maj 1844", Grundtvig-Studier 2005, København, 68-71.

- (2005 II), "Breve til og fra Grundtvig, marts-juni 1844", GrundtvigStudier 2005, København, 72-85.

Høirup, H. (1949), Grundtvigs Syn paa Tro og Erkendelse, København.

Lundgreen-Nielsen, Flemming (2007), "Grundtvig og censuren", GrundtvigStudier 2007, København, 44-90.

Nørfelt, Henrik Fibiger (1983), En ny Sang i Danas Mund, København.

Pedersen, Johs. (1920), Israel I-II, København.

Thodberg, Chr. (1989), Syn og Sang, København.

- (2005), "Grundtvigs krise i foråret 1844. Forholdet mellem prædiken og salme med henblik på 'Sov sødt, Barnlille'”, Grundtvig-Studier 2005, København, 38-67.

Toldberg, H. (1950), Grundtvigs Symbolverden, København.

Schiøler, Aage (2004), "Den kirkelige anskuelse som svar til Karon", Grundtvig-Studier 2004, København, 179-233.

- (2007), "Sangmotivets funktion i to sæt tekstvarianter hos Grundtvig", Grundtvig-Studier 2007, København, 108-147.

Stevns, M. (1940), "Nogle Naturbilleder fra Grundtvigs Salmer", Fra Grundtvigs Salmevorksted, 1950, København, 26-57.

\section{Skønlitteratur}

Borum, Poul (1996), Digte til Musik, København.

Ewald, Johannes (1775), "Rungsteds Lyksaligheder" i V. Kuhr (udg.) Johannes Ewalds samlede Skrifter, bind 3, København (1916), 88-90.

Hansen, Martin A. (1952), Orm og Tyr, København.

Larsen, Martin (udg.) (1955), Njal og branden på Bergthorshvol, København. Nielsen, Hans Jørgen (udg.) (1963), Haiku, København.

Wessel, Johan Herman (1784), "Smeden og Bageren" i K. L. Rahbek (udg.) Johan Herman Wessels samtlige Skrifter, Første Deel, 2. udg., København (1729), 286-291.

\section{Noter}

1 Den af mig foretrukne brug af 'tillige' har en parallel i salmeudgaven på syv strofer af digtet "Blomstre som en Rosengaard", 1853 (GSV IV, 343344). Den er samtidig med "Midt iblandt os" og indeholder linjerne:

Ære med vor høie Drot,

Med hans Aand tillige!

Begge de giør Alting godt

I vort Himmerige;

(str. 6, v. 1-4) 
"Begge" rettes i Festsalmer, 8. opl. 1864, til "Sammen", der understreger Sønnens og Åndens fællesskab (GSV VI/2, 334) og er gået videre i senere salmebøger.

Den samme brug af 'tillige' findes også i ældre salmer, hvor den ved nævnelsen af den treenige Guds navn understreger Guds enhed. Det bedst kendte eksempel herpå er nok DDS03 11, str. 3, v. 1-2: "Gud Fader med Guds Søn / og Helligånd tillige”. Andre er DDS03 16, 1 og 740, 2.

Uafhængigt af gudsnavnet findes den hos Brorson i linjen "O! springer, I dale og bierge tillige" (BSS II, str. 7, 318). Derimod er uafhængigheden af gudsnavnet kun tilsyneladende hos Grundtvig selv i linerne:

Som Foraars-Solen morgenrød

Stod Jesus op af Jordens Skiød

Med Liv og Lys tillige!

(GSV II, str. 1, 250)

"Liv og Lys" er ved udgivelsen af Sang-Vark (...) II, 1870, rettet fra "Lys og Liv" i 1846 (GSV IV, str. 4, 201), en rækkefølge, der også forekommer i digtet "Lyset og Livet er Tvillinger bolde", 1837 (GSV I, 313-315). Her er ordparret en betegnelse for Guds nærværs skikkelse på jord og i den betydning brugt om Sønnen og Ånden som disses billedsproglige repræsentationer og $\mathrm{i}$ en forbindelse, der gennem omtale af et undtagelsestilfælde markerer deres fælles optræden:

Lyset og Livet, som trøste i Vaanden,

Det er Guds Naades det levende Ord,

Det er guddommeligt Sønnen og Aanden,

Hjerternes Midler og Trøster paa Jord,

Og hvad end Døden adskiller herneden,

De kun adskildtes Lang-Fredag forleden,

Kun da den Eenbaarne opgav sin Aand!

(str. 3)

På grund af Skaberordets identitet med Kristus som Ordet kan det samme forhold foreligge i henvisningen til Opstandelsen og Åndens komme ovenfra:

Lyset og Livet i Frelserens Kirke,

Som de giør Eet i Guds mundtlige Ord,

Tidlig opstod, for end sildig at virke,

Og med de glødende Tunger nedfoer!

(str. 4, v. 1-4)

Også i slutstrofens første linjer møder vi denne sammenstilling:

Lyset og Livet vi glade velsigne,

Ydmyg tilbede Guds Søn og Guds Aand,

Som os vil lære Gud-Fader at ligne,

(str. 9, v. 1-3)

Det bibelske holdepunkt for sammenstillingen af lys og liv/liv og lys som betegnelse for Gud i hans relation både til verden $\mathrm{i}$ almindelighed og til mennesket i særdeleshed har Grundtvig fundet i Johs 1, 4, der i AO1992 
direkte udsiger disse metaforers personale karakter i deres tilknytning til Gud som Ordet: "I ham var liv og livet var menneskenes lys", som det tydeliggøres i Johs 1,14:"Og Ordet blev kød og tog bolig blandt os, og vi så hans herlighed".

På den baggrund er det næsten uundgåeligt at se "med lys og liv/med liv og lys tillige" som betegnelse for, at Guds Ånd og Guds Ord optræder som ubrydelig enhed ved Jesu tilbagekomst til disciplene efter nedfarten til Helvede, altså den samme tankegang som i linjerne "Med Guds Aand og i Guds Ord, / I Guds Menighed tillige".

Hansen I 1937, 265-266, ser "Lyset og Livet" som et opgør med rationalismen. Hovedvægten lægges på, hvordan "Lyset og Livet" sammen møder os i menigheden. Toldberg 1950, 119-121, sætter begrebsparret i en sammenhæng, der fører perspektivet helt frem til Jesu Genkomst.

2 Til denne betydning af "giæste", se $O D S$, s.v. II. Gæste, 2), hvor der blandt eksemplerne anføres: 'Du skal blive gjæstet og bespist som Thor' (hos Udgårdsloke? - min tilf.). Se også GSV IV/2, sp.2, 335.

Den dynamiske gæst dukker også op hos Brorson i billedet af de salige hos Gud i evigheden:

$\mathrm{Nu}$ holde de, og har til best,

Hos ham en ævig Løfsals Fest;

Og Lammet selv,

Ved Livets Elv,

Er baade Vært og Giest.

(BSS III, str. 2, 124)

Her skal man ikke lade sig distrahere af, at Brorson synger om det himmelske måltid. Både Lukas: "For jeg siger jer: Jeg skal aldrig mere spise <påskemåltidet>, før det fuldendes i Guds rige" (Luk 22,16), og Grundtvig: "Halleluja for Herrens Bord / I Himlen hist og her paa Jord!" $(G S V$ V, str. 11, 501) ser "Naadebordet" som foregribelse af måltidet $\mathrm{i}$ evigheden.

3 Det stilfærdige præg, der kendetegner str. 3, når den nævner, at "Aanden kalder" "med Herrens Stemme", bringer tanken hen på naturbillederne i pinsesalmen "I al sin Glands nu straaler Solen" med den betagende tredje strofe:
Det aander himmelsk over Støvet,
Det vifter hjemlig giennem Løvet,
Det lufter liflig under Sky
Fra Paradis, opladt paany,
Og yndig risler ved vor Fod
I Engen Bæk af Livets Flod!
(GSV VI/2, 268)

En lignende billedbrug ses i slutstrofen fra "Guds Herren saae til Jorden ned":

Naar da, som Vinden Skyer blaa,

Din Aande blidt mig driver,

Da skal mit Hjerte godt forstaae,

Hvordan Du Synd tilgiver, 
Og i det samme Jesu Navn,

Som raader Bod paa alle Savn,

Skal Salighed jeg finde!

(GSV IV, str. 7,107-108; min kursivering i v. 2)

Her møder vi igen det (af Grundtvig) fremhævede "Jesu Navn", der også dukker op i str. $4 \mathrm{i}$ "Midt iblandt os".

Bag disse billeder gemmer sig antagelig fortællingen om Elias i hulen på bjerget Horeb:

"Da lød det: 'Gå ud og stil dig på bjerget for Herrens ansigt, så vil Herren gå forbi’.

Forud for Herren kom en voldsom og kraftig storm,

der splintrede bjerge og knuste klipper,

men Herren var ikke i stormen.

Efter stormen kom et jordskælv, men Herren var ikke i jordskælvet.

Efter jordskælvet kom en ild, men Herren var ikke i ilden.

Efter ilden lød en sagte susen.

Da Elias hørte det, tilhyllede han sit ansigt med kappen, gik ud og stillede sig i hulens åbning. Da lød der en stemme: 'Hvad vil du her, Elias'” (1 Kong. 19,11-13). Elias hørte Herrens stemme i en sagte susen, men så ikke Herren.

Med brug af en klassisk teologisk formulering kunne man sige, at Den lille Katekismus næsten udelukkende samler sig om 'fides quae', mens Grundtvig desuden må være opmærksom på 'fides qua'. For Luther er det aldeles nødvendigt og altafgørende at præcisere, hvad den kristne tro tror på. Grundtvig måtte også tage hensyn til den tro, den kristne tro tror med. De ortodokse dogmatikere havde af nødvendighed udviklet rigide detailafgrænsninger over for andre kristne trossamfunds læresystemer. Oplysningstænkerne havde i sammenhæng med naturvidenskabelige landvindinger som for eksempel de af Newton afdækkede love om tyngdekraften gennemført en isolering af den teoretiske fornuft som eneste kilde til sand erkendelse. Pietisternes trosopfattelse var i høj grad blevet psykologiseret. Ingen af dem tilfredsstillede Grundtvig. Alle tre truede de kristendommen som historisk fænomen. Derfor måtte opgøret komme. Sådan kan det udtrykkes i en koncentreret form, der nærmer sig parodien.

5 Opslag i $H B$ viser den hyppige forekomst af både 'fornemme' og 'smage' i den del af Grundtvigs salmer, der er kommet i brug ved gudstjenester og kirkelige handlinger. Her kan man også se, at begge ord er blevet brugt, men i mindre omfang, af tidligere salmedigtere, ikke mindst af Brorson. Nøjere læsning viser, at hans brug ofte har et tydeligt emotionelt præg, mens Grundtvigs hovedsagelig knytter sig nær til bibelsk sprogbrug eller sin egen erkendelsesteori.

6 En omhyggelig omtale af etheasámeta findes i $R B, 43-46$.

7 Denne afvisning af Ordet er dog ikke Grundtvig ukendt. Knyttet til inkarnationen findes den blandt andet i "En Sædemand gik ud at saae", 
1837, str. 7-9 (GSV I, 327), og i "Fuglen har Rede, og Ræven har Grav", 1856, str. 2-4 (GSV V, 19-20).

8 Forekomsten af tilsvarende kataloger hos græske filosoffer fra samme tidsrum viser den almenmenneskelige interesse for disse fænomener. De var ganske enkelt del af hine tiders 'gymnasiepensum' (Engberg-Pedersen 1994, 115-116). Forskellen mellem Paulus og hans samtidige består i, hvem eller hvad der foranlediger friheden til ret handlen og færden. Hos Paulus er det éntydigt Kristus (1 Kor 1,30).

9 Befrielsespotentialet $\mathrm{i}$ "sød" viser sig i tre meget forskellige, men velkendte salmer. Kirkesalmen "Tør end nogen ihukomme", 1825, sætter "Hjertets søde Morgen-Drøm" over for "al Verdens Domme" (GSV I, str. $1,60)$. De sidste er bestemt af periodens negative forhold til 'gammeldags kristendom', og derfor er der en befrielse inden for tidens kategori gemt $\mathrm{i}$ den "søde Morgendrøm", som det viser sig i linjerne: "Thi skal Herligheden vorde / Større i vort Bonde-Huus" (GSV I, str. 11, 63).

Himmelfartssalmen "Kommer Sjæle, dyrekøbte", 1837, har den dramatiske modsætning "Helved hedt og Himmel sød" (GSV I, str. 7, 475). Hos Grundtvig er Helvede prototypen på ufrihed og fangenskab, som det ses helt tydeligt i nabosalmens indledende linje: "I Kveld blev der banket paa Helvedes Port", 1837 (GSV I, str. 1, 471), og i salmen "Al den ganske Christenhed", 1855, hvor det hedder om Kristus: "Blev korsfæstet, lagt $\mathrm{i}$ Jord, / Og til Fængselet nedfoer" (GSV IV, str. 2, 471). Befrielsespotentialet i "sød" tegnes i himmelfartssalmen i den rumlige kategori gennem den ekspansive kraft i midterstroferne (GSV I, str.4-6, 474-475).

I "Gudsbarnets Vuggesang", kendt som "Sov sødt, Barnlille", er "sød" i alle tre versioner knyttet til englevagten i str. 1 og til Frelserens navn i sidste strofe som værn mod Djævelens anfald (GSV IV, 47-48; 255-257. V, 529). Glosen dækker altså ikke over en selvfølgelig idyl, som det også fremgår af salmens baggrund i digterens mentale vilkår på tilblivelsestidspunktet. Det drejer sig om et eksistentielt anliggende, en befrielse til at stole på Guds nærhed (Ertner 1997. Jette Holm 2005 I og II. Thodberg 2005).

Også i Grundtvigs folkelige forkyndelse har "sød" denne betydningsnuance. Det kan ses i digtet "Modersmaalet", 1837 (US VIII, 179-183). Det er en lovsang om særpræget ved det danske sprog, især når det lyder som "Moders Røst" og "i Pigemunde". I samtlige 21 strofer lyder omkvædet:

Sødt i Lyst og sødt i Nød,

Sødt i Liv og sødt i Død,

Sødt i Eftermælet!

Den lettelse og tryghed og det lyssyn, der gennemtrænger digtet, bliver yderligere nærværende, når man erindrer sig tidspunktet for dets tilblivelse. Det blev trykt som indledningsdigt til afhandlingen Skolen for Livet og Akademiet $i$ Soer, der udkom i foråret 1838, men blev efter sigende skrevet mellem jul og nytår 1837 samtidig med, at digteren fik brev om, at hans ansøgning om fritagelse for den censur, han havde været underlagt siden 1826, var blevet imødekommet (HGS I, 58-59. US VIII, 179). 
Censuren havde vist ikke haft praktisk betydning i den forstand, at den havde hindret Grundtvig i at udgive noget, bortset fra "Om Religions-Frihed", 3. del, 1827 (US V 95-153), men den havde plaget ham personligt og principielt, se hertil "Om den Clausenske Injurie-Sag", 1831 (US V 356-364). Nu kunne han atter frit tale, skrive og få sine ting trykt. Der er muligvis ikke tale om et direkte inspirationsforhold mellem ophævelsen af censuren og lovprisningen af modersmålet, som i skjaldens viser bæres fra slægt til slægt af mødre og døtre, men måske alene tale om et tidsmæssigt sammenfald (således Dam 1999, 8). Eventuelt har meddelelsen om skrivefriheden mindet digteren om et andet, lignende anliggende, nemlig folkets frihed, som han havde tumlet med i hvert fald siden 1834, udtrykt i ønsket om skabelsen af et dansk folkeligt akademi, der blandt andet skulle virke for denne frihed (Gylden-Aaret, 1834; US VIII, str. 44-45, 19. HGS I 40). Lundgreen-Nielsen 2007 bringer en udtømmende gennemgang af Grundtvigs forhold til censuren og trykkefriheden gennem hele forfatterskabets forløb.

Uanset baggrund, inspiration og anledning er befrielseselementet et gennemgående træk i digtet. Lige inden slutstrofens ønske om, at det danske sprog må leve i "Smaapigernes Maal det søde", når digtet sit højdepunkt i den konkluderende, næstsidste strofes åbenhed:

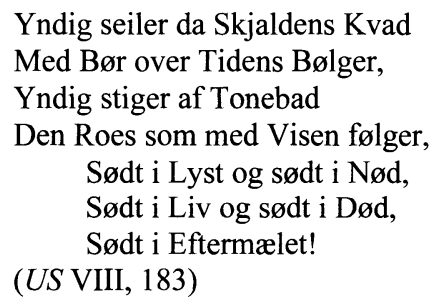

hvor fællesnavnet "Skjalden" givetvis også gemmer Grundtvig i sig. I "Gud Herren saae" møder vi et lignende mønster i forbindelse med nåden, men uden at freden er nævnt, i linjerne:

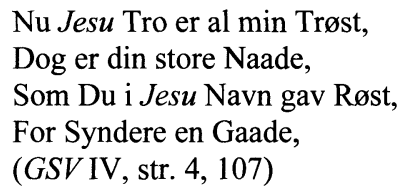

hvor "Jesu Tro" er den tro, Jesus kalder frem (subjektiv genitiv).

11 Ensartetheden i Guds Riges måde at komme ind i vores verden på ved inkarnationen og i nadveren gør den tekstændring mulig, Grundtvig foretager i 1868:

Og naar Herrens Himmel-Glæde

Raabes ud med Aande-Røst, (GSV VI/2, sp. 1, 335)

Se Schiøler 2007, 122-123. 
12 Der er forskel på brugen af blomst/frugt-motivet her og i definitionen af "Naturens Orden" i Aabent Brev til mine Børn", 1839:
Kun Spiren frisk og grøn i tidlig Vaar,
Og Blomster-Floret i den varme Sommer,
Da Modenhed imøde Planten gaaer,
Og fryder med sin Frugt, naar Høsten kommer!
(US VIII, 188)

Set med Grundtvigs øjne gælder det for os, at tiden løber i en bestemt retning, men for Gud, at "Hans Timer og Dage / Gaae frem og tilbage" (Nyaars-Morgen, 1824. US IV, str. 47, 263). Se også Schiøler 2004, note 15, 229-230).

13 Udtrykket 'at frede' er antagelig foranlediget af betegnelsen 'fredskov', der i 1805 indgik i den forordning, som forhindrede, at store skovarealer i Danmark blev ryddet. Som bekendt bruger Grundtvig fredskoven som metafor for menigheden i pinsesalmen over alle pinsesalmer "I al sin Glands nu straaler Solen", 1843 og 1853 (GSV VI/2, str. 2, facsimile ved 268), og opblomstringen bestemmes i den sammenhæng præcist som virkning af Ånden "i Ordets Navn" (GSV III, str. 4, 515).

14 I salmen "Til klart Guds Ansigt vi skal see", 1837 og 1853 (GSV I, 228231; IV, 324-325), beskrives tro, håb og kærlighed i første strofe som værktøjer i Guds hånd til at begynde og fuldende Guds gerning. "Naaden", "Aanden" og "Christus" er i kronologisk orden ophavsmand til, at treklangen indfinder sig (GSV I, str. 1, 128; IV, 334; VI/2, sp. 2, 333). Der er ikke tænkt på selvberoende, menneskelige egenskaber, hvis afkast i omgivelserne og menneskesindet kan påvises. Snarere er der tale om en art kompetencer, Gud tilfører mennesket, tager i brug og opøver og udfolder gennem sin tiltale i evangeliet og livets tilskikkelser. Det sker på en måde, så menneskets eneste grund til at henholde sig til dem er, at det har Guds ord for det i Jesu menneskeskæbne.

En anden variant af forståelsen af tro, håb og kærlighed som eksternt funderede fænomener møder vi i høstsalmen " $\mathrm{Nu}$ falmer Skoven trindt om Land", 1844 (GSV IV, 50-51), hvor treklangen i sidste strofe:

Hans Aand, som Alting kan og veed,

I disse korte Dage,

Med Tro og Haab og Kjærlighed

Til Himlen os ledsage!

kan sammenlignes med den kombination af råd, opmuntring og vejledning, en mentor yder den uerfarne.

15 Vi møder her det samme syn på denne gåen fejl og vilkåret for dens udbedring som i Nordens Mytologi, 1832, i underafsnittet UniversalHistorisk Vidskab i bogens "Indledning”. Det væsentlige er ikke, hvilket navn man vil give det, Grundtvig i den sammenhæng kalder "et stort Uheld". "Hoved-Spørgsmaalet er (...), om Skaden kan helbredes paa naturlig Maade eller ikke" (US V, 401-402). Grundtvigs fastholden af det sidste fremgår af, at dåben ses "som et virkeligt Gienfødelsens Bad, hvori den Troende aandelig omskabes" (s. 402), hvorimod naturalisten af ånd mener det første. Fremhævelserne er Grundtvigs. 
16 Tanken om dåben som redskab for Kristus som den nye Skaber, genfødslens iværksætter, udfoldes yderligere i salmen "Alle mine Kilder skal være i dig", 1856-60, med titlen "Livs-Kilden i Daaben" (GSV V, 257-258). Efter omtale af "det Folkefærd uden Mage" (str. 1), Jesu fødsel og dåb (str. 2-3), vores dåb, "det Bad som er uden Mage" (str. 4), og efterfølgelsens dåb, "som i Jorden Dale / Vorherre han bærer skjult hos sig" (Mark 10, 35-45, jf. Luk 12, 50) (str. 5), sluttes med strofen:

Alle mine Kilder skal være i dig

Af dig gienfødes skal Jord og Himmel

Folks og Tungers og Stjerners Vrimmel

Med alt hvad Jeg evig bar hos mig.

Den talende er naturligvis Gud som Far: Skaberen og Opretholderen. Gennem den dåb, Gud som Søn: Frelseren og Befrieren, tager på sig, genoprettes skaberværket i sin oprindelige godhed (1 Mos 1,31).

Salmebøgerne bruger "hos dig" i v. 1 i alle strofer. Denne form er hentet i Salmer og aandelige Sange, udgivet af den grundtvigske Salmefond, bind 3, $1873(G S V \mathrm{VI} / 3$, sp. 2n, 415) og kan være godkendt af Grundtvig (AMI, 54).

Tanken om, at Jesus er den, der udfører dåben, kan også gemme sig i salmen "Helligaanden trindt paa Jord", 1860 (GSV V, 200). Her hævder str. 4 om dåb og nadver:

Det er sandt og det er stort,

Det har Jesus Christus gjort,

Det har Herren, som vor Næste

Naadig gjort til fælles Bedste,

Evigt Liv med Salighed.

Ligheden bliver desto større, hvis beskrivelsen i str. 2 af den handlende faktor ved dåben:

Livets Ord af Guddoms-Rod

Kilden er til Livets Flod

ikke ser "Livets Ord" isoleret som trosbekendelsen ved dåben, men også inddrager Kristus som Ordet, Lyset og Livet fra Johs 1,1-4. Brugen af "Livets Træ" om nadveren i str. 3 kunne tyde på det. Her er Jesus som det sande vintræ fra Johs 15 antagelig på færde.

Den samme tankegang møder vi i "Den levende Christus", 1847, med de præcise linjer om dåb og nadver:

Hans Bad er Livets Jordansflod,

Hans Bord er Livets Træ paa Rod,

(GSV IV, str. 9, 226)

Forståelsen af fuldendelsen som afklaring forekommer også i digtet om den kristne tro: "Jeg er saa underfuld en Magt", 1829 (GSV I, 33-36), hvoraf Grundtvig udskriver salmen "Vidunderligst af alt paa Jord", 1853 (GSV II, 385-386). Formuleringen har ved omarbejdelsen vundet $\mathrm{i}$ klarhed og korthed: 
Da er mit Værk tilende,

Hvad Troende i Speilet saae,

Skal Salige erkiende!

Om Han end tøver, troe Ham dog!

Han Ingen har bedraget,

Som, trods al Prat om Billed-Sprog

Paa Ordet Ham har taget!

Ja, komme skal Han som et Lyn,

For Alt at aabenbare,

Af Guddoms-Glands for Sagn da Syn

Skal faae min Helgen-Skare!

Ja, Christenhed! syng du kun frit:

For Vid jeg vælger Lykken,

Thi som Hans Ord er over mit,

Han selv er over Skyggen!

(GSV I, str. 26-29, 36) (GSV II, str. 11-12, 386)
Er Christnes Kamp tilende, Hvad Troende i Speilet saae, Skal Salige erkiende
Da Riget er med Sole-Kaar
Tilsyne og tilstæde,
I Evighedens Gylden-Aar
Med Ret og Fred og Glæde!

Den talende er i 1829 “Christus-Troen”, i 1853 er salmen digterens direkte forkyndelse af Guds Rige.

Når "i det Blaa" som her kombineres med den endelige afklaring ved Kristi Genkomst, støtter det forståelsen af paralleludtrykket "i Sky" som udsagn om den guddommelige sfære. Begge tekster henviser direkte til 1. Kor 13,12 ved at sætte den negative del af denne passages første led: at se i et spejl, over for det andet leds positive del: at erkende fuldt ud. "Midt iblandt os" hentyder med "Synlig som han selv" antagelig til det samme skriftsteds tale om at se ansigt til ansigt. For så vidt "forklares" i denne salme indbefatter et element af at få bedre indsigt, har vi her også en hentydning til korinterbrevsstedets udsagn, at "da skal jeg kende fuldt ud, ligesom jeg selv er kendt fuldt ud". I 1853 træder Guds Rige med dets kendetegn fra Rom 14,17, i stedet for det upræcise "Alt" fra 1829.

Hos Grundtvig er farven blå i øvrigt kun en entydigt positiv bestemmelse, når den gælder himlen og kærminden. Meget kendte eksempler på det første er "Deilig er den Himmel blaa", 1810 (GSV II, str. 1, 197), og "Med venlige Øine himmelblaa", 1825 (GSV I, str. 4, 405). Mere i familie med anvendelsen i "Jeg er så underfuld en Magt" og "Vidunderligst af Alt paa Jord" er betydningen i linjerne

Som han opstod,skal vi opstaae (...)

Opfare til ham i det Blaa,

(GSV III, str. 11, 503)

og

Jesus, himmelfaren, Udsender Engle-Skaren

Al Jorden rundt til sine Smaa

At vinke dem til Himlens Blaa!

(GSV IV, str. 2, 251) 
I andre forbindelser har glosen en betragtelig betydningsbredde, der endda $\mathrm{i}$ forbindelse med læber og negle rækker til at betegne død. Henvisninger til brug i salmer kan ses i $H B, 37-38$, og til anden brug i Toldberg 1950, 318.

I linjen "For Vid jeg vælger Lykken" (GSV I, str. 29, 36) som troens udsagn, ses "Vid" vel bedst som et kortere udtryk for det "Mandevid", der over 40 år senere er magtesløst over for døden i Grundtvigs sidste digt:

Stormene er frygtelige,

Stille staaer her Mandevid,

(GSV V, str. 2, 628)

Her over for står "Lykken" som den livbringende gave, der ganske overraskende og ufortjent tilskikkes eller vederfares os. Sagen er meget malende beskrevet ud fra gamle tiders skik med at meddele øvrighedens bestemmelser til sognefolket i forbindelse med søndagens gudstjeneste. Det sker i en strofe fra salmen "Øine, I var lykkelige", 1864, der som strofen fra 1829 er knyttet til Kristus som Guds Ord:

Held os, Christne paa det Jævne!

Naadens Tid er ei forbi,

Som oplyst paa Kirke-Stævne,

Lykkens Skiødebørn er vi,

Øine seer og Øren høre

Ham, som har Guds Ord at føre.

(GSV V, str. 3, 519-520)

Dette åbne træk ved fremstillingen af eskatologien i str. 9 medfører, at mennesker med meget forskellige forestillinger om det endelige og afgørende møde med den Gud, Jesus fra Nazareth giver navnet Far, kan finde sig til rette i strofens udsagn herom. indpasse:

Kingos beskedent formede, men indholdsrige bøn, lader sig

Lad da uden Tiid og dage

Mig dit Æris Ansigt see!

Synd og Sorrig, Vee og Klage

Rodne med min Joorde-Blee.

(KSS III, str. 15, 19; jf. DDS03 739, 7)

Her minder de to første linjer om 1 Kor 13,12, om at se ansigt til ansigt. Fra $G T$ kan der tænkes på forestillingen om Guds ansigt i den aronitiske velsignelse $(4$ Mos 6,26$)$ og på håbet om en ophævelse af vilkåret: "Du får ikke lov at se mit ansigt, for intet menneske kan se mig og beholde livet" (2 Mos 33,20). De to sidste kan være inspireret af Åb 21,4:

Han vil tørre hver tåre af deres øjne, og døden skal ikke være mere,

ej heller sorg, ej heller skrig, ej heller pine skal være mere.

Thi det, der var før, er forsvundet. 
Der er i Grundtvigs fire, korte linjer også så vidt til væggene og så højt til loftet, at der er plads til Brorsons mere detaljerige, men særdeles stilsikre gengivelse af billederne i Åb 7, 9-17:

Den store, hvide Flok vi see,

Som tusind' Bierge fuld af Snee,

Med Skov omkring

Af Palme-Sving (...)

Der holde de nu Kirke-Gang,

Med u-ophørlig Jubel-Klang,

I høje Chor,

Hvor GUd han boer

Blant alle Englers Sang

(...)

$\mathrm{Nu}$ holde de og har til best

Hos ham en ævig Løfsals Fest;

Og Lammet selv,

Ved Livets Elv,

Er baade Vært og Giest.

(BSS III, str. 1 og 2, 123-124)

Fra langt nyere tid skal nævnes den i sin lakoniske nøgternhed vellykkede slutlinje: "Og der er ingen Grave", fra K. L. Aastrups ellers noget ujævne gengivelse af Wirséns "En vänlig grönskas rika dräkt". Linjen kan ses som endnu en henvisning til Åb 21,4 (Aastrup, str. 5, 69. Wirséns tekst: DSP1921 644).

Også uden for salmedigternes kreds møder vi udsagn om 'de sidste tider', der kan opfanges af str. 9. Meget markant i Martin A. Hansen: Orm og Tyr, 1952, 248-254, med modstillingen af sjæletro og opstandelsestanke. Et andet skønlitterært eksempel er de sidste linjer i det afsluttende, men kronologisk set ikke nødvendigvis sidste digt "I'M BEGINNING TO SEE THE LIGHT" i Poul Borums sidste digtsamling:

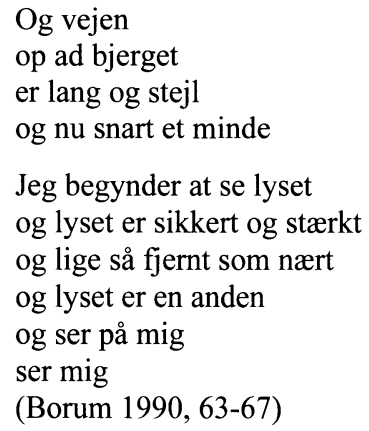

Lyset, åbenheden og 'ansigt til ansigt'- motivet er fælles træk med sidste strofe i "Midt iblandt os", selv om de fremstår på baggrund af vores kår, mens Grundtvig umiddelbart forud har præciseret Guds indgriben.

De skiftende udtryk for den endegyldige befrielse og afklaring, der rækker fra den drabelige apokalyptik i det 1 . århundrede over barokkens praktiske sansefylde og rokokoens stilsikre elegance i 1700-tallet til 
1900-tallets nøgterne minimalisme og meddigtende historiefortælling, lader sig altså opfange af Grundtvigs bibel- og billedbaserede sproglige univers.

19 En anden udformning af forårsbilledet som metafor for sårbarheden har vi i Wirséns i note 17 omtalte "En vänlig grönskas rika dräkt" på originalsproget og i K. L. Aastrups gengivelse. Derimod dæmpes spændingen mellem forgængelighed og evighed i Johannes Johansens gendigtning (DDS03 725), fordi den med 'Guds ord' allerede i str. 1 indfører Herrens ord i form af skaberordet, og fordi den udelader gentagelsen af "Alt kött er hö" i str. 4.

Når en tekst lader sig fremføre sangligt, er det nærliggende at inddrage forholdet mellem tekst og melodi som hjælp til forståelse af teksten. Det er navnlig et brugbart middel, når der som i dette tilfælde er flere melodier med forskelligt grundpræg til rådighed.

Lindemans melodi (DDK03 211) er den, der først blev brugt til salmen. Melodisk forekommer den for svingende i forhold til salmens stilfærdige diktion: kvint nedad i 1. takt, oktav opad mellem 2. og 3. takt og kvint opad i 5. takt. Rytmisk skaber brugen af hele to takter til strofernes sidste tre stavelser en opbremsning, der ikke svarer til tekstens fremadrettede præg. Den krydrede harmonisering i takt 5-7 passer dårligt til den neutrale sprogbrug, der er fremherskende i strofernes 3. linje.

Niels W. Gades melodi (DDK03 305) er oprindeligt skrevet til en 'åndelig børnesang': "Lover Gud! I Barndoms stille”. Derfra stammer vel dens charmerende og milde præg. Senest i 1873 kom den i brug til Grundtvigs "Kirken er som Himmerige", 1851 (GSV IV, 294-295), der også blev sunget i menigheder uden for Vartov. Melodiens smidige og venlige forløb ligger nær en renlivet idyl, som ikke er ganske ideel til "Midt iblandt os". De centralt kristne motiver, salmen mediterer over, kræver en anden form for opmærksomhed end den, idyllen har brug for. Det gælder allerede i str.1, hvor "Hans Naadebord" peger hen også på Skærtorsdag og dens alvor. Det fortsætter med spændingen i str. 2 mellem Guds Riges virkelighed og vores vilkår i forhold til det: "Synligt ei", med gåden i str. $5 \mathrm{og}$ med nødvendigheden af rensning og fredning $\mathrm{i}$ str. 8. Først i slutstrofen forsvinder denne spænding helt. Den erstattes imidlertid ikke af en stille idyl, svarende til den i Gades melodi, men af en åben frihed. Rytmisk sinker fermaten i sidste takt forløbet mellem stroferne, mens harmoniseringen ikke giver anledning til bemærkninger.

Laubs melodi (DDK03 224) er oprindeligt skrevet til Kingos "Hvilestunden er i vente" (KSS III, 346-347), ændret til strofisk form til brug i $R T$, nu DDS03 762. Melodien er antagelig indsunget til "Midt iblandt os" gennem højskoler og folkelige møder. Både melodisk og rytmisk svarer den fint til tekstens enkle ordvalg og det trokæiske versemål. Dernæst respekterer opdelingen af melodien med en enkelt, moderat halvslutning $\mathrm{i}$ 4. takt den sammenhæng, der er i de enkelte strofer, og slutningen indbyder til et nyt åndedrag, svarende til fremdriften $\mathrm{i}$ teksten og åbenheden $\mathrm{i}$ dens sidste linje. Endelig passer harmoniseringen i sin klarhed til det enkle sprog. Halvslutningens og slutningens Dur-kadencer 
løfter den til et stilfærdigt, støttende niveau i pagt med det meditative, men ikke passive præg i teksten.

I Thomas Kingos Aandelige Siunge-Koor, 1684, har teksten overskriften "Dend 4. Afften-Suk" (KSS III, 346) og er ikke opdelt i strofer. Det giver sig udtryk i kommaet mellem str. 4 og 5 i DDS03 762. Takken i disse to strofer danner overledningen mellem meditationen i str. 1-3 og bønnen i str. 6-8 med tryghedserklæringen i de to sidste linjer. Det meditativt-svævende præg i Laubs melodi er antagelig inspireret af disse forhold. Det er ikke noget dårligt udgangspunkt for brug til en salme, som har visse fælles træk med "Aften-Sukkets" momenter af det meditative.

Samlet hørt virker Lindemans melodi for urolig i forhold til tekstens sproglige udtryk, mens Gades er for stillestående i forhold til fremdriften i dens tankegang. Ved sanglig fremførelse medbringer de på hver sin vis momenter, der er teksten fremmed. Laubs melodi giver plads til både eftertanke og bevægelse og står på den måde ikke $\mathrm{i}$ vejen for tekstens særpræg.

Korte, melodihistoriske oplysninger findes i Nørfelt 1983, 12. 